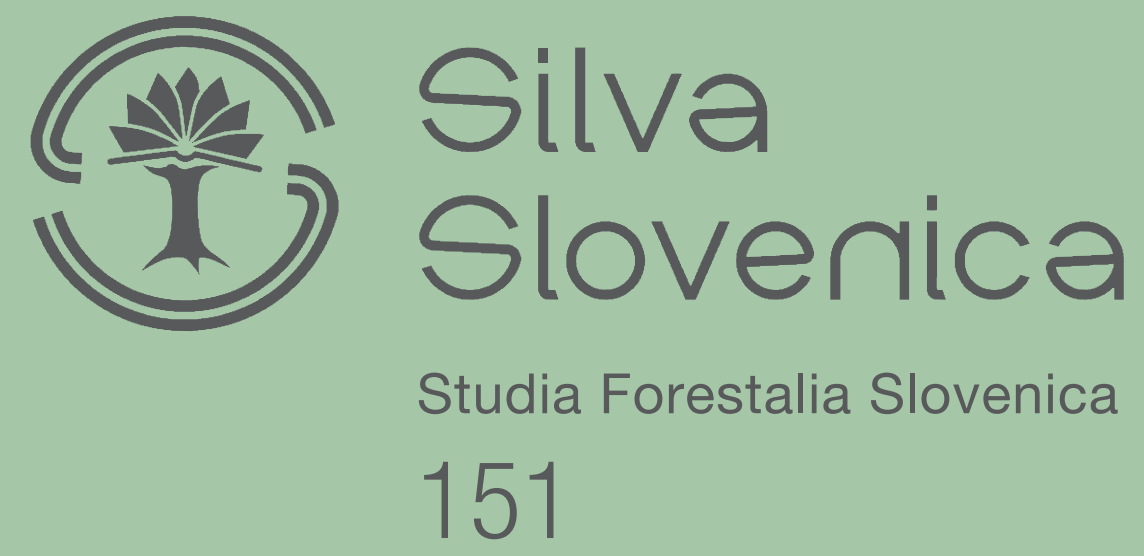

\title{
SHORT REVIEWS ON THE GENETICS AND BREEDING OF INTRODUCED TO EUROPE FOREST TREE SPECIES
}

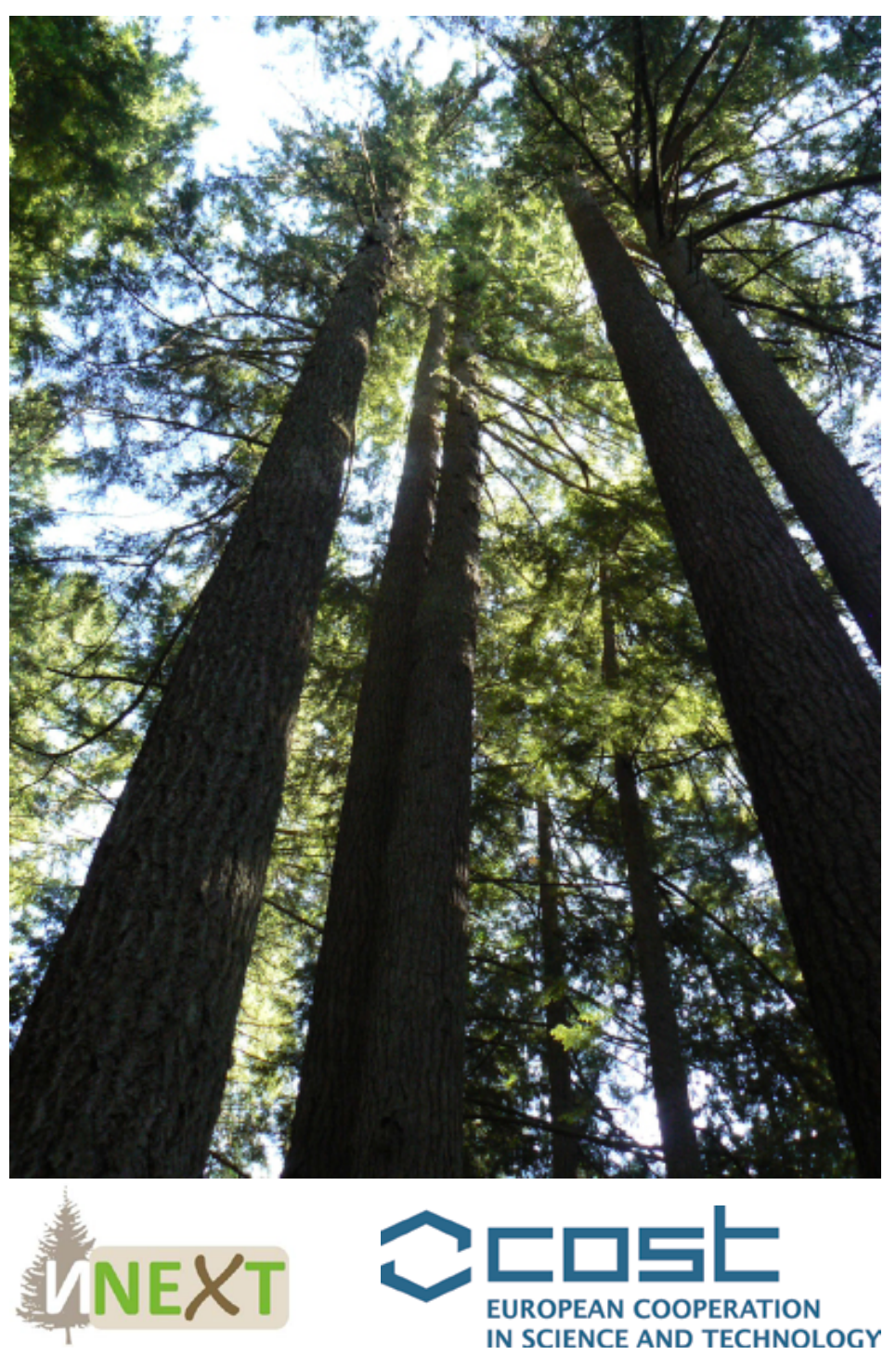


Studia Forestalia Slovenica, 151

ISSN 0353-6025

\section{ISBN 978-961-6993-19-7 (pdf)}

Publisher: Slovenian Forestry Institute,

Silva Slovenica publishing centre, Ljubljana 2016

Title: Short reviews on the genetics and breeding of introduced to Europe forest tree species

Chapters edited by: Dr. Monika Konnert and Prof. Dr. Paraskevi Alizoti

Technical editor: dr. Peter Železnik

Front page foto: M. Konnert, Douglas-fir stand in Washington, USA

Edition: $1^{\text {st }}$ electronic edition

Price: free

Electronic issue:

http://dx.doi.org/10.20315/SFS.151

Acknowledgement:

The work has been carried out within the COST Action FP1403 Nonnative tree species for European forests - experiences, risks and opportunities (NNEXT), Working group "Pathways".

\section{Disclaimer:}

The short reviews were not subjected to external peer review. The responsibility lies solely with the authors.

Kataložni zapis o publikaciji (CIP) pripravili v Narodni in univerzitetni knjižnici v Ljubljani

COBISS.SI-ID $=287954432$

ISBN 978-961-6993-19-7 (pdf)

\section{Table of contents}

2 Editorial

2 Monika Konnert, Paraskevi Alizoti

3 Abies grandis

Jean Charles Bastien

6 Cedrus atlantica and Cedrus libani Monika Konnert

9 Juglans nigra Marcela van Loo

13 Larix kaempferi and Larix x eurolepis

16 Picea sitchensis Georg von Wühlisch

20 Pinus contorta Bo Karlsson, Johan Kroon

25 Pinus strobus Paraskevi Alizoti

$30 \begin{aligned} & \text { Pseudotsuga menziesii } \\ & \text { Monika Ronnert }\end{aligned}$

36 Quercus rubra Marjana Westergren

40 Robinia pseudoacacia Marcela van Loo, Renata Milcevicova, Marjana Westergren 


\section{Editorial}

Introduction of non-native to Europe forest tree species dates back to the 18th century when the wood demand, due to Europe's industrialization, was extremely strong. The main species introduced initiallywere fast growing ones, such as Douglas fir (Pseudotsuga menziesii), Sitka spruce (Picea sitchensis), Grand fir (Abies grandis), Lodgepole pine (Pinus contorta), Robinia (Robinia pseudoacacia), Red oak (Quercus rubra). Besides their potential for high wood production, the adaptive potential of certain non-native species to harsh environmental conditions, related to climate change, rendered them as species of high importance. The introduction of non-native species in the past resulted, in various cases, in adaptation failure and economic loss, as the origin of the introduced genetic material was not considered. The up to now experience and scientific knowledge dictate that the initial selection of the appropriate non-native species and geographic origin within species for introduction to Europe should be based on genetic knowledge and the breeding results obtained from programs carried out within the species natural range.

In the current issue of Studia Forestalia Slovenica, and in order to serve the above purpose, ten short reviews on the genetics and breeding of twelve important to Europe non-native species (Abies grandis, Cedrus atlantica, Cedrus libani, Juglans nigra, Larix kaempferi, Larix x eurolepis, Picea sitchensis, Pinus contorta, Pinus strobus, Pseudotsuga menziesii, Quercus rubra, Robinia pseudoacacia) are published. The short reviews were compiled by WG2 - 'Pathways' members of the Cost Action FP 1403 NNEXT (Non-Native Tree Species for European Forests: EXperiences, Risks and OpporTunities).

December 14, 2016

Monika KONNERT - Paraskevi ALIZOTI 


\title{
Abies grandis
}

\author{
Jean Charles Bastien \\ INRA - Centre Val de Loire, 2163 Avenue de la Pomme de Pin, CS 40001 ARDON \\ 45075 ORLEANS Cedex 2, France
}

\section{Natural distribution range}

Grand fir (Abies grandis (Douglas ex D. Don) Lindley) grows naturally in northwestern United States and southern British Columbia (Canada), while its geographical distribution ranges from latitude $51^{\circ}$ to $39^{\circ}$ $\mathrm{N}$. and from longitude $125^{\circ}$ to $114^{\circ} \mathrm{W}$. Its coastal range stretches along the Pacific coast from southern British Columbia to Northern California. Its continental range extends in eastern Washington and Oregon, northern Idaho and western Montana. Grand fir grows generally on acid, rich and deep soils, and on a variety of sites with a mean annual precipitation range from $360 \mathrm{~mm}$ (eastern Oregon) to $2500 \mathrm{~mm}$ (western Washington). Depending on the site, growing season can vary from 3 months (Idaho) up to 8 months (California).

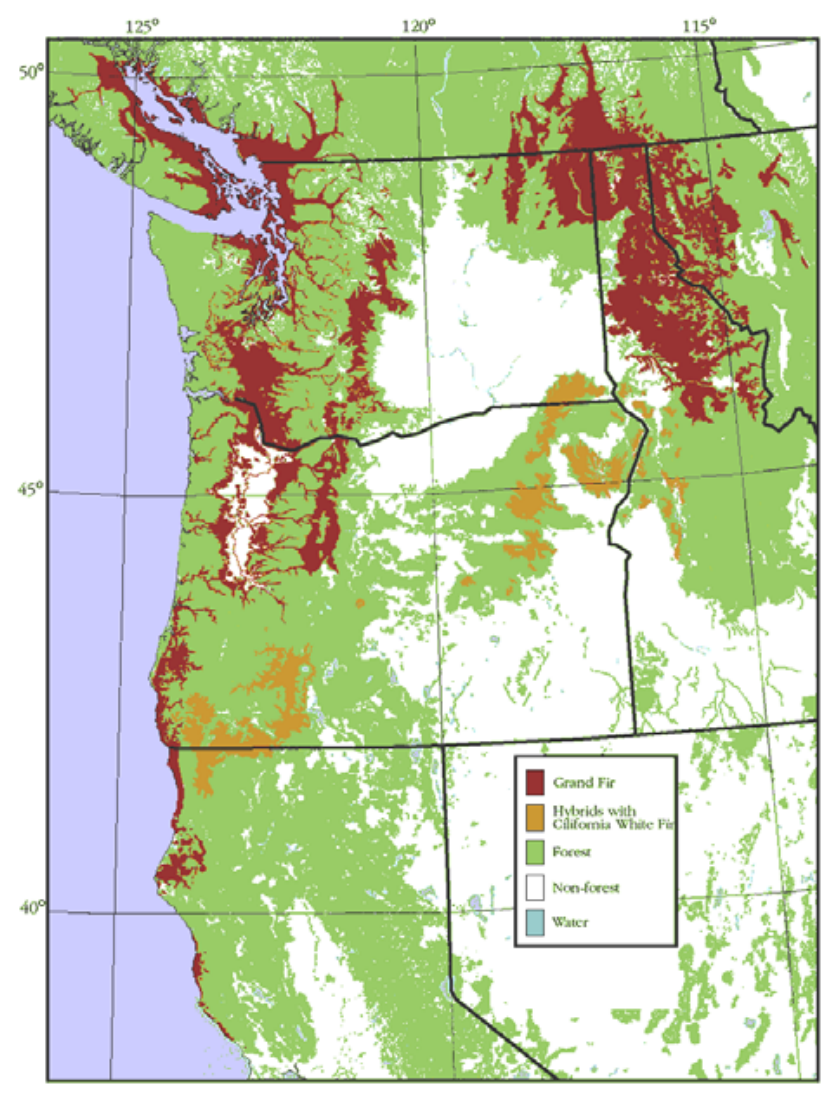

Figure 1. Abies grandis natural range (in dark brown) [Source: Van Pelt (2002)]
Grand fir intercrosses with both varities of white fir, i.e. Abies concolor (Gord. \& Glend.) Lindl. ex Hildebr. and Abies lowiana (Gordon \& Glend.) A. Murray, considered as a variety of Abies concolor (Steinhoff, 1978). Introgression zones between grand fir and the two white fir varieties are recognized in northern California through southwestern Oregon and through the Oregon Cascade Range into northeastern Oregon and west-central Idaho (Steinhoff, 1978).

\section{Genetic Variation}

\section{a. Adaptive genetic variation}

\section{Results of breeding efforts within the species natural range}

In its natural range, Abies grandis, as well as other firs, is considered as a minor forest species compared to more predominant species like Pseudotsuga menziesii, Pinus contorta, or Picea sitchensis. It is generally planted for ecological reasons or to foster stand resilience through species richness. Based on the literature, there is virtually no breeding activity on Grand fir.

In USA, a Grand fir private seed orchard from coastal origin has been reported (Cress and Daniels - 1990: Simpson timber seed orchard - Shelton - alt. 90 m). This seedling seed orchard has been planted on 5 acres (about 2 ha) in 1978. In Idaho, the Inland Empire Christmas Tree Association (IECTA) runs a small Grand fir seed orchard (19 trees - 40 years old) near Sandpoint, ID.

In British Columbia (Canada) the forest genetics program for Abies grandis focuses on provenance testing, aiming towards testing seedlings originating from sources across the species' range in different sites and environmental conditions. Periodically, these trials are measured to evaluate Grand fir's level of adaptation at the various test sites. Results have been of value to produce seed transfer guidelines for the tested provenances. Fast 
growing populations were also being identified and effects of climate change on the species could be predicted. Moreover, superior trees of coastal and interior origins have been grafted for gene conservation purposes, as well as for potential non recognized till now uses (Woods 2014).

\section{Results of breeding efforts in Europe}

In Europe, most of the knowledge on Abies grandis genetic variability is based on the research carried out in the framework of the IUFRO network of provenance trials (41 seed lots collected in 1976 over the whole natural distribution range). Results for three major traits (frost resistance, growth and wood density) are summarized below:

\section{- Frost resistance:}

In a provenance test planted at $800 \mathrm{~m}$ elevation in Poland, Dolnicki and Kraj (1998) was observed that Abies grandis provenances exhibited weaker frost fall hardiness than Abies alba. However, only two provenances of the species were characterized by similarly high hardiness; namely the eastern Oregon (elev. $1400 \mathrm{~m}$ ) and the western Washington (elev. $825 \mathrm{~m}$ ) ones.

Based on results obtained from one year old grand fir seedlings, Larsen and Ruetz (1980) reported that their frost resistance (early, winter and late frost) increased with the increase of the distance of their place of origin from the coast. The most inland provenances were also the last to bud burst. In the specific trial the Oregon provenances proved to be less frost resistant than the Washington ones. Elevation alone had no significant influence on the frost resistance.

\section{- Growth Traits:}

Based on measurements carried out in 18 Abies grandis provenance tests in central and northern Germany, Rau et al. (2008) and Kleinschmit et al. (1996) showed that for height and volume the fastest growing provenances originated from low to mean elevations in the Pudget Sound area, from the Vancouver Island, from southern Washington west of the Cascades and from northern Oregon. Nearly all central and southern Oregon provenances were growing slowly. A significant positive correlation of growth traits with latitude was recorded. Mean volume differences between provenances ranged among $30 \%$ to $176 \%$. An overall ranking including height, diameter, and losses showed that 7 Washington provenances, 3 British Columbia provenances and 1 Oregon provenance surpassed the overall mean by at least $10 \%$. These results are also supported by the findings reported later on by König (2007), Kulej and Socha (2008) and Kulej (2010).
In Great Britain, Samuel (1996) tested the growth of different seed lots of Abies grandis originating from 36 locations, that were representing almost all the natural range of the species. Performance was evaluated in 10 experimental sites, 15 years after planting, by measuring height and breast height diameter. Provenances from northern coastal Washington performed better, followed by provenances from British Columbia (Canada) and southern coastal Oregon. Washington provenances Louella (1005) and Elma (1003) outperformed all other provenances in most of the test sites. Similar results were obtained by Kranenborg (1995) in the Netherlands, Vancura and Veran (1995) in Czech Republic and Bastien (1995) in France.

\section{- Wood density:}

Polge (1968) compared the tree ring width and the within ring density of 3 years old seedlings that represented 25 Abies grandis provenances. The results of this study raised the interest on using the percentage of summer wood to discriminate populations of the species. Percentage of summer wood of continental (interior) provenances ranged among 75 to $80 \%$, whereas, for the coastal or French land races, the percentage ranged among 62 to $73 \%$.

In a provenance test planted in France, Bastien (1995) observed that at the age of 19 years a strong and unfavorable relationship existed between diameter growth and wood density. However, four fast growing provenances, all originating from the northern part of the Puget Sound in Washington State, broke this type of correlation, exhibiting fast growth and comparatively higher wood density. This observation was also supported by the findings of Samuel (1998).

\section{b. Neutral genetic variation}

To our knowledge only the publication of Konnert and Ruetz (1996) - reported results on the differentiation of Abies grandis based on genetic markers. Genetic analysis of 9 isozyme loci was carried out to investigate the genetic structure of 11 Abies grandis sources, out of which 9 were populations tested in a 17 years old field trial and 2 were commercial seed collections. Pronounced differences were identified among the different sources for the polymorphic gene loci Idh-B and Pgm-A. When all gene loci were jointly considered there was a clear regional differentiation between provenances from Washington/British Columbia and western Oregon, while the northern provenances had higher genetic diversity and heterozygosity. The provenance Post $(1450 \mathrm{~m})$ from central Oregon (Interior) exhibited by far the highest genetic variability together with a very specific genetic structure and thus, it could not be assigned to any one of the two regional groups. 


\section{Natural regeneration in Europe}

In its natural range, Grand fir regenerates satisfactorily on most sites after overstory's removal to encourage rapid growth in height and diameter.

In a monograph on Abies grandis, Konnert and Ruetz (2009) reported that due its shade tolerance, the natural regeneration of the species is feasible in Germany, as long as there is a good weed and understory control.

In an experiment undertaken in Wykeham forest in North England to monitor the effect of enrichment planting with 25 different species to increase the productivity of a first rotation stand of Pinus sylvestris, a number of Abies species was included (A. grandis, A. procera, A. concolor, A. nordmanniana, and $A$. veitchii). Mason (2012) reported that 10 years after the process of transforming the evenaged stands to irregularly structured ones only Abies procera, Abies grandis and Abies veitchii have successfully contributed to the development of the enriched Pinus sylvestris stand. The natural regeneration cohort was dominated by Abies species which were $65 \%$ of seedlings and saplings in the thinned plot and $97 \%$ in the unthinned plot, while in the thinned plot both seedlings and saplings were present in nearly equal proportions and Abies species comprised over 60 per cent in each category.

\section{References}

Bastien, J.C. (1995): Grand Fir provenance experiment Forêt Domaniale de Chaud. Joint Meeting of the IUFRO Working Parties S2.02.05, 06, 12 and 14. Limoges-France Aug. 1-4 1995.

Dolnicki, A., Kraj, W. (1998): Dynamics of frost resistance in various provenances of Abies grandis LINDL. Acta Societatis Botanicorum Poloniae - Vo. 67, No. 1: 5158.

Kleinschmit, J., Svolba, J., Rau, H.M., Weisgerber, H. (1996): The IUFRO Abies grandis provenance experiment in Germany - Results at age 18/19. Silvae Genetica 45, 5-6.

König, A. O. (2007): Herkunftsdifferenzierung von Abies grandis im norddeutschen Tiefland und Mittelgebirgsraum sowie Empfehlungen zur Provenienz Wahl. Forst und Holz, 62/7, 14-17.

Konnert, M., Ruetz, W. R. (1997): Genetic variation among provenances of Abies grandis from the Pacific Northwest. Forest Genetics 4(2): 77-84.
Kranenborg, K.G. (1995): Abies grandis provenance research in The Netherlands. Joint Meeting of the IUFRO Working Parties S2.02.05, 06, 12 and 14. Limoges-France Aug. 1-4 1995.

Kulej, M., Socha, J. (2008): Effect of provenance on the volume increment of grand fir (Abies grandis Lindl.) under mountain conditions of Poland. Journal of Forest Science, 54, (1):1-8.

Kulej, M. (2010): Adaptive ability of different provenances of grand fir (Abies grandis Lindl.) in the montane zone of Poland - the LZD Krynica case study. Annals of Warsaw University of Life Sciences - SGGW, Forestry and Wood Technology, 73: 75-81.

Larsen, B., RuetzW.F. (1980): Frostresistenz verschiedener Herkünfte der Douglasie (Pseudotsuga menziesii) und der Küstentanne (Abies grandis) entlang des 44. Breitengrades in Mittel Oregon. Forstw. Cbl. 99: 222-233.

Mason, W.L. (2012): The Role of True Fir Species in the Silviculture of British Forests: past, present and future. Kastamonu Univ., Journal of Forestry Faculty, 2012, Special Issue; p 15-26.

Polge, H. (1968): Tests précoces de la qualité du bois sur 25 provenances d'Abies grandis. Annales des sciences forestières, 25 (1), p.3-23.

Rau, H.M., König, A., Ruetz, W., Rumpf, H., Schönfelder, E. (2008): Ergebnisse des westdeutschen IUFRO-Küstentannen-Provenienzversuches im Alter 27. Beitrage aus der NW-FVA, Band 4; 63 p.

Ruetz, W.R. (2009): Abies grandis. Enzyklopädie der Holzgewächse - 57. Erg.Lfg. 03/11; 1 - 10.

Samuel, C.J.A. (1996): The influence of seed origin on the growth of Grand Fir in Britain. Forestry Commission, Research information Note 280, 6 p.

Steinhoff, R. J. (1978). Distribution, ecology, sylvicultural characteristics, and genetics of the Abies grandis-Abies concolor complex. In Proceedings of the IUFRO joint meeting of working parties, vol. 2: Lodgepole pine, sitka spruce, and Abies provenances. p. 123-132. B. C. Ministry of Forests, Vancouver, B. C.

Vancura, K., Beran, B. (1995): Results on North American firs IUFRO tests in the Czech Republic. Joint Meeting of the IUFRO Working Parties S2.02.05, 06, 12 and 14. Limoges-France Aug. 1-4 1995.

Van Pelt, R. (2002): Forest Giants of the Pacific Coast. University of Washington Press, 200 p.

Woods, J. (2014): Ministry of Forests, Lands and Natural Resource Operation; Forest Genetic Council of British Columbia; 60 p. 


\title{
Cedrus atlantica and Cedrus
}

\section{libani}

\author{
Monika Konnert \\ Bayerisches Amt für forstliche Saat- und Pflanzenzucht, Forstamtsplatz 1, 83317 Teisendorf, Germany
}

\section{Natural distribution range}

\section{Cedrus libani}

Cedrus libani A. Rich. can be found in eastern Mediterranean and in two main distribution areas, namely in Turkey, and in particular in South and Southwest Anatolia, and in a geographically distinct occurrence in Lebanon (along the Mt. Lebanon) and Syria. In Turkey the species distribution includes large parts of the west and middle Taurus and the Amanos mountain areas and extends to around 400.000 ha. Due to heavy depletion the distribution of Cedrus libani is fragmented in many small populations. Larger populations can be found mainly in the western Taurus. In Lebanon the natural distribution range has declined from 500.000 ha, to 1.700 ha for the same reasons as in Turkey.

\section{Cedrus atlantica}

The natural distribution range of Cedrus atlantica (Endl.) Batt.\& Trab. is highly fragmented and is restricted to the north African regions of Morocco and Algeria (Linares et al. 2011). In Morocco Cedrus atlantica can be found in the mountainous areas of Rif, Middle-Atlas and High-Atlas.
The species meets its optimum in the Middle-Atlas region and in altitudes between 1600 and $2200 \mathrm{~m}$. In Algeria, the main regions where the species can be found are the Tell-Atlas and Sahara-Atlas. The whole distribution range covers an area of 145.000 ha.

\section{Genetic Variation}

\section{a. Adaptive genetic variation}

\section{Results of breeding efforts in Europe}

Literature on breeding programs in the natural range of the species is scarce. Significant efforts have been made though in southern European countries regarding the two species.

\section{Provenance trials - Cedrus libani}

Provenance trials established in Turkey, Italy and France showed that the Turkish provenances of Cedrus libani exhibit a more vivid growth compared to the provenances originating from Lebanon. In addition, they exhibit better



Figure 1. Cedrus atlantica and Cedrus libani distribution range (Data source: Google Earth) 
resistance against drought, and thus a higher survival rate in arid summers. The Turkish provenances reveal a later bud break (20 days) than the ones originating from Lebanon. Among the Turkish provenances those originating from the East- or Central Turkey show the best results, while in the marginal areas of the distribution range the positive properties diminish.

Based on those results the following recommendations for the cultivation of Cedrus libani can be made:

- For cultivation purposes in Turkey, provenances from the central- and eastern Mediterranean region shall be preferred.

- For afforestation in France, four proveniences from the eastern distribution area can be recommended.

- For cultivation purposes in Italy, Turkish provenances should be preferred in general.

- Early-sprouting provenances from Lebanon have to be avoided, although they must be safeguarded for the conservation of the species diversity.

\section{Provenance trials - Cedrus atlantica}

In general, provenance trials were carried out for both species Cedrus libani and Cedrus atlantica together. Cedrus atlantica has a slightly later bud burst, thus being even more resistant to late frosts. Although in terms of growth, Cedrus atlantica is superior when compared to Cedrus libani in most cases, Cedrus atlantica shows less resistance against drought. Within the species, some provenances from Algeria show a higher tolerance against drought than those from Morocco and thus they should be preferred. Studies in Hungary show that after a slow start, the increase of growth is huge. Thus at the age of 36, the wood stock for Cedrus atlantica is $550 \mathrm{~m}^{3} / \mathrm{ha}$.

The different behaviour of the provenances enables the accurate choice of the genetic material for planting :

- For cultivation purposes, the French naturalized provenances (origin Algeria), Mont Ventoux, Tikjda, Barbors and Chèlia should be preferred.

- In Italy, provenances from Middle- or High-Atlas are recommended because of a superior growth.

- In arid conditions, provenances from Sahara-Atlas show best results.

Cedrus libani, Cedrus atlantica as well as their hybrids are used in various plantations e.g. in France, Portugal, Italy. Being outside of the natural range, these plantations represent in fact breeding programmes of both species
(Carvalho et al. 2007, Fady et al. 2003, Bariteau 2015). As an example the research project "Global, physiological and molecular responses to climatic stresses of three Mediterranean conifers" (09/1997-08/1998) within the INCO-DC framework involved 6 countries, including France, Israel, Italy, Morocco, Tunisia and Turkey. The gathered information should be used for application in afforestation, breeding and gene conservation programmes (INRA 2015).

\section{b. Neutral genetic variation}

Genetic variation has been recorded for the Cedrus species by using isozymes (Scaltsoyannes 1999, Fady et. al. 2000) RAPDs and AFLPs (Fady et al. 2003), as well as chloroplast and nuclear microsatellites (Chaib et al. 2006, Fady et al. 2008). For some isozyme gene loci (IDH-A, LAP-A, 6-PGDH-B), species specific alleles were detected which can help to distinguish between Cedrus atlantica, Cedrus libani and Cedrus deodara. Generally a high genetic variation within populations, but also a high genetic differentiation between the different species and varieties, was found based on all marker types. Populations of Cedrus libani from Lebanon, Turkey and Cyprus constitute genetically isolated groups, while the cedar of Cyprus is recognized as a separate species, i.e. Cedrus brevifolia A.Henry ex Elwes \& A.Henry. Populations in Turkey in general are characterized by extensive gene flow and thus relatively low differentiation, while there is little evidence of genetic drift within populations. In contrast gene flow in the populations of Lebanon seems to be low, resulting in high differentiation and severe cases of genetic drift (Scaltsoyannes 1999, Fady et al. 2008). For Cedrus brevifolia from Cyprus Eliades et al. (2011) report high genetic diversity within and between populations based on cPSSR and nSSR loci. High genetic variation within populations and higher genetic distances between some populations were also determined for Cedrus atlantica in Morocco. Investigations provided evidence that Moroccan populations comprise of two genetically distinct groups (Renau-Morata et al. 2005, Terab et al. 2006). RAPD and AFLP markers were used by Fady et al (2003) to study hybridization and introgression between Cedrus atlantica and Cedrus libani. No indication of strong reproductive isolation barriers among the Mediterranean Cedrus taxa was found. 


\section{Natural regeneration in Europe}

More than fifty years ago Cedrus atlantica was successfully used for afforestation in southern France. Today the surface of afforested zones in France is over 20.000 ha (Bariteau and Vauthier 2011). The species has showed a good natural regeneration capacity. The progenies of the planted French stands have a good height growth on both calcareous and acid soils. Both species regenerate naturally but the regeneration success depends on soil conditions and human influences.

In planted forests were both Cedrus atlantica and Cedrus libani grow together there was no indication of strong reproductive isolation barriers among the two taxa. (FADY et al. 2003). Hybridization and introgression is possible.

\section{References}

Bariteau, M., Vauthier, D. (2011): Main results from the French Cedar comparative field test Network. In: Besacier Ch., Ducci F., Malagnoux M., Souvannavong O. (Eds.): Status of the Experimental Network of Mediterranean Forest Genetic Resources. CRA SEL, Arezzo and FAOSilva Mediterranea, Rome, Italy: 61-64.

Bariteau, M. (2015): Adaption and selection of Mediterranean Pinus and Cedrus for the sustainable afforestation of marginal lands. URL: https://ec.europa. eu/research/agro/fair/en/fr0097.html [Stand: 18.09.2015]

Carvalho, J., Loureiro, A., Bariteau, M. (2007): Provenances trial of Cedrus atlantica Manetti in northeastern Portugal. In: Besacier Ch., Ducci F., Malagnoux M., Souvannavong O. (Eds.): Status of the Experimental Network of Mediterranean Forest Genetic Resources. CRA SEL, Arezzo and FAO-Silva Mediterranea, Rome, Italy: 65-67.

Chaib, J., Danan, S., Jouaud, L., Hagen, S., Lefevre, F., Fady, B. (2006): Identification and characterization of nuclear microsatellites in Mediterranean cedar (Cedrus ssp.) Mol. Ecol. Notes 6: 840-842.

Eliades, N.G.H., Gailing, O., Leinemann, L., Fady, B., Finkeldey, R. (2011): High genetic diversity and significant population structure in Cedrus brevifolia Henry, a narrow endemic Mediterranean tree from Cyprus (2011) Plant Syst Evol 294: 185-198.
Fady, B., Bariteau, M., Fallour, D., Giroud, E., Lefèvre, F. (2000): Isozyme gene markers and taxonomy of Mediterranean Cedrus species. - In: Panetsos, K. (ed.): Adaptation and selection of Mediterranean Pinus and Cedrus for sustainable afforestation of marginal lands. Giahoudi-Giapouli, Thessaloniki, Greece, 21-26.

Fady, B., Lefèvre, F., Reynaud, M., Vendramin, G. G., Bou Dagher-Kharrat, M., Anzidei, M., Pastorelli, R., Savouré, A., Bariteau M. (2003): Gene flow among different taxonomic units: evidence from nuclear and cytoplasmic markers in Cedrus plantation forests. Theoretical and Applied Genetics 107: 1132-1138.

Fady, B., Lefèvre, F., Vendramin, G. G., Ambert, A., Règnier, C., Bariteau, M. (2008): Genetic consequences of past climate and human impact on eastern Mediterranean Cedrus libani forests. Implications for their conservation. Conservation Genetics 9: 85-95.

INRA (2015): Global, physiological and molecular responses to climatic stresses of three Mediterranean conifers. URL: http://www.pierroton.inra.fr/INCO/. [Stand: 18.09.2015]

Linares, J. C., Taïqui, L., Camarrero J. J. (2011): Increasing Drough Sensitivity and Decline of Atlas Cedar (Cedrus atlantica) in the Moroccan Middle Atlas Forests. Forests 2: 777-796.

Renau-Morata, B., Nebauer, S. G., Sales, E., Allainguillaume J., Caligari P., Segura J. (2005): Genetic diversity and structure of natural and managed populations of Cedrus atlantica (Pinaceae) assessed using random amplified polymorphic DNA. American Journal of Botany 92(5): 875-884.

Scaltsoyannes, A. (1999): Allozyme differentiation and phylogeny of cedar species. Silvae Genetica 48: 61-68.

Terrab, A., Paun, O., Talavera, S., Tremetsberger, K., Arista, M., Stuessy, T. F. (2006): Genetic diversity and population structure in natural populations of Morroccan Atlas cedar (Cedrus atlantica; Pinaceae) determined with cpSSR markers. American Journal of Botany 93(9): 12741280 . 


\title{
Juglans nigra
}

\author{
Marcela van Loo
}

University of Vienna, Department of Botany and Biodiversity Research, Rennweg 14, 1030 Vienna, Austria

\section{Natural distribution range}

Black walnut (Juglans nigra L.) also known as eastern black walnut is one of six Juglans species from the Section Rhysocaryon (black walnuts), which are endemic to the North America. This tree species is native to the deciduous forests of the eastern United States (USA) from Massachusetts to Florida and west to Minnesota and Texas, and occurring naturally in southern Ontario (Canada). The majority of black walnut trees occur in natural stands, with walnut plantations (ca. 13,800 ac) accounting for $1 \%$ of all the black walnut volume $(\mathrm{ft} 3)$ in the USA (Shifley 2004).

Commonly, black walnut's distribution is scattered; it does not grow in large, uninterrupted stands as do many conifers. Also pure stands can be found only seldom. It grows along

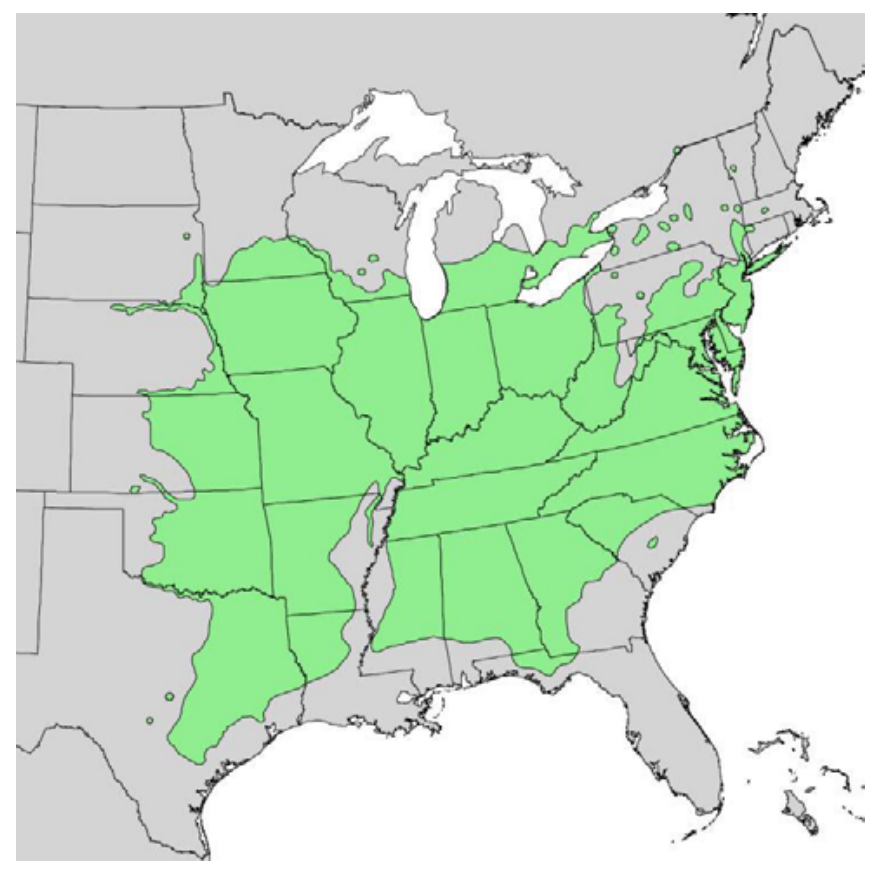

Figure 1. Natural distribution of Eastern black walnut within 33 states of USA (after Little 1971). bottomlands and is associated with river systems. Pollen dispersal is by wind; seed dispersal is by gravity, rodents, and more recently by humans. In most parts of its natural range, humans have heavily exploited walnut. Naturally, walnut grows in rich moist sites with deep well-drained soils. Foresters have long ago recognized that walnut is site-sensitive and has a natural tendency to grow crooked and forked, without strong apical dominance and with a great deal of variability in form and growth rate (Woeste and McKenna 2004, Victory et al. 2004).

\section{Genetic Variation}

\section{a. Adaptive genetic variation}

\section{Results of breeding efforts within the species natural range}

Breeding efforts were initiated by the establishment of provenance tests which indicated that the origin of seed collection affected the timing of leaf flush and leaf fall, and tree height. Trees from the southern sources flushed earlier, lost their leaves later, and were generally taller and of larger diameter (because of longer growing seasons) (Bey 1973). Bresnan et al. (1994) reported that the local trees had the highest survival rates (from within 100 miles north or south of the plantation) at all studied locations, while growth traits such as height and breast height diameter exhibited a significantly high correlation across all the tests they established. It was also demonstrated that trees originating from seed sources collected up to 200 miles south of the planting site grew significantly taller than trees from more northerly locations (Bey 1973, Bresnan et al. 1994). This particular result led to the so-called "the 200-mile guideline", according to which the northward movement (max. 200 miles) of genetic material results in significantly faster growth when compared to the growth of the local seed sources. Black walnut seed zones were proposed initially in the absence of genetic data, based upon temperature, annual precipitation, and occurrence of frost in the spring and fall, the number of frost-free 
days, latitude, and summer day length (Deneke et al. 1987).

Breeding programs in the beginning were concentrated largely on nut production and quality of the black walnut. Since 'Thomas' was named as America's first black walnut cultivar in 1881 (Corsa 1896), cultivar development has proceeded haphazardly. Throughout the 20th century over 700 cultivars have been named (Berhow 1962, Reid 1997) and the percent of edible kernel has improved two-fold (seedling walnuts average 17\% kernel while some cultivars consistently produce over 34\% kernel).

By the end of the 1960s, when efforts toward timber production improvement just started, there were already 18 nut cultivars that were widely used for nut production in the Central Hardwood Region. Although single-species plantations of black walnut for timber production date from as long as the late 1800s, modern efforts in genetic research were initiated by Johnathan Wright and Leon Mincler in the early 1950s (Michler et al. 2007).

After it became clear that walnut was extremely site sensitive and that significant environment $\mathrm{X}$ genotype interactions would confound genetic effects and complicate their interpretation (Geyer and Rink 1998), the efforts towards black walnut timber breeding was tempered in later years. Today, efforts are still underway to breed a fast-growing, straight- boled, black walnut timber varieties (Woeste and McKenna 2004).

Since 1982 several breeding and improvement programs and cooperatives were established. The NC-99 program (began in 1960) focused on determining the range and pattern of genetic diversity, breeding, selection and seed production, breeding zones, and advanced generation breeding for species of economic importance. The NC99 program contributed significantly to the knowledge accumulated on breeding black walnut (Stier 1986). The eight-state Fine Hardwood Tree Improvement Cooperative (began in 1986) genetic improvement of primarily black walnut.

\section{Results of breeding efforts in Europe}

Four provenance tests have been established in southern United Kingdom according to Kerr (1993). The results indicated that the species is extremely sensitive to the site conditions and should only be planted on the most suitable frost free, fertile, well drained and deeply rootable sites. It was also proved that Juglans nigra is more tolerant to poor sites than Juglans regia, while all Juglans nigra provenances originating from Vermont, Ohio and Illinois performed well on the best site in the Chilterns and relatively well on the other poorer sites.
Russell and Hemery (2004) reported that 32 provenances were targeted, 20 from the United States (across 13 States in eastern North America) and 12 from Europe. Goal of their effort is to identify superior black walnut trees that can act as seed trees or be cloned for timber production. The established provenance/progeny trials are expected to be assessed for survival, flushing, vigor (height and diameter), form, and occurrence of anthracnose.

The black walnut $\mathrm{x}$ Persian walnut (i.e. Juglans regia) hybrid (J. $\mathrm{x}$ intermedia) has received considerable attention as a potential timber tree. The French hybrid progeny (resulting from French breeding program) of J. $x$ intermedia, known as hybrid cultivar ' $\mathrm{Ng} 23 \mathrm{xRa}$ ', is an outstanding hybrid cultivar. It is well known for its vigor, growth habit and suitability to northern European growing conditions (Fady et al. 2003). This hybrid is also in the U.K. market (www.walnuttrees.co.uk/timber home.htm). Also, the Department of Mediterranean Trees at the Institut de Recerca i Tecnología Agroalimentàries (IRTA) initiated a research program in 1993 to examine the variability among walnut species for wood production and to establish orchards with improved selections (e.g. $\mathrm{Ng} 23 x$ Ra' (. $\mathrm{x}$ intermedia). The main objective of the program is to breed new hybrid progenies of Persian x black walnut for wood production adapted to Spain's Mediterranean climate (tests of heterosis for the F1 Progenies of Juglans nigra X Juglans regia L.) in order to increase the variability in the current breeding germplasm, which is represented mainly Persian walnut.

\section{b. Neutral genetic variation}

Isoenzyme studies of only 5 populations located in the eastern part of the distribution range (5 US States out of the 33 where J. nigra is naturally distributed) did not reveal any major genetic subdivisions among five widely dispersed provenances. Nevertheless, they detected the Aat-lb allele of the Aat-1 locus only in one US-state in Wisconsin (Busov et al. 2002). More intensive sampling will be needed to determine if the allele has a limited distribution throughout the range of black walnut and can be used for provenance-specific assignment of genotypes and/or for verifying seed source identity. Nuclear microsatellites (nSSRs), genotyped for larger number of loci than the isoenzymes, showed higher levels of allelic richness than studied isoenzymes in Juglans nigra (Busov et al. 2002) but did not revealed any apparent geographical pattern (Victory et al. 2006). In more detail, 43 populations (1250 trees in total) widely distributed in the central hardwood region of the USA (in 10 states) and genotyped for $12 \mathrm{nSSRs}$ were remarkably genetically homogenous: with low Fst and in a Bayesian analysis the optimal higher-order partition was into a single group comprised of all 43 populations (Victory et al. 2006). 
An effort for association mapping in natural populations of the species is under way aiming towards the identification of gene networks that influence tolerance to biotic (lethal TCD) and abiotic stress. Goal of this intensive effort is also to develop genomic resources for existing breeding programs and for natural populations and it is expected to facilitate also the conservation of the species. Association mapping study (https://pag.confex.com/pag/ xxi/webprogram/Paper4910.html) (Fernow et al. 2013).

\section{Natural regeneration in Europe}

Black walnut's scattered occurrence, shade intolerance, and short-distanced seed dispersal calls for artificial regeneration and plantation management. Open-grown trees produce seed as early as 8 years after planting, the minimum seed-bearing age for commercial quantities of seed is about 12 years. Best seed production begins when the tree is about 30 years old and continues for another 100 years. Many black walnut seedlings germinate from the nuts cached by squirrels in the fall. Normal freezing and thawing usually causes the seeds to break dormancy the following spring, but germination is often delayed, sometimes until the second year. Control of competing vegetation is especially important in new plantations for the first 3 to 4 years (Beineke 1989).

The species hybridizes naturally with Juglans regia and their hybrid J. $\mathrm{x}$ intermedia is superior to both species in terms of increased vegetative vigour, distinct disease resistance, good wood quality and greater winter-hardiness (Fady et al. 2003). For these reasons is this hybrid interesting for forestry, especially in Northern Europe. In addition, being an important rootstock, these hybrids play a role in horticulture as well. Nevertheless, the hybridization under natural conditions is rare and still difficult by using controlled pollination. The hybridization barriers are mainly due to flowering asynchrony among the two species, differences in the floral morphology and the conspecific pollen advance (Pollegioni et al. 2013).

\section{References}

Corsa, W. P. (1896): Nut culture in the United States. Special report to the Secretary of Agriculture. U.S. Department of Agriculture, Division of Pomology. Washington, DC: Government Printing Office, 144 p.

Beineke, W. F. (1989): Twenty years of black walnut genetic improvement at Purdue University. Northern Journal of Applied Forestry 6: 68-71.

Berhow, S. (1962): Black walnut varieties- a reference list. Northern Nut Growers Association Annual Report 53: 6369.

Bey, C. F. (1973): Growth of Black Walnut trees in eight midwestern States - a provenance test. USDA Forest Service Research Paper, North Central Forest Experiment Station.

Bey, C. F. (1980): Growth gains from moving black walnut provenances northward. Journal of Forestry 78: 640-641.

Bresnan, D. F., Rink, G., Diebel, K. E., Geyer, W. A. (1994): Black walnut provenance performance in seven 22 year-old plantations. Silvae Genet. 43: 246-252.

Busov, V. B., Rink, G., Woeste, K. (2002): Allozyme variation and mating system of black walnut (Juglans nigra L.) across the Central Hardwood region of the United States. For. Genet. 9: 319-326.

Deneke, F. J., Funk, D. T., Bey, C. F. (1987): Preliminary seed collection zones for black walnut. USDA For.Serv.Northeast Area State and Private For. NA-FB/ M-4. 5p.

Fady, B., Ducci, F., Aleta, N., Becquey, J., Diaz Vasquez, Fernandes Lopez, F., Jay-Allemand, C., Lefevre, F., Ninot, A., Panetsos, K., Paris, P., Pisanelli, A. and Rumpf, H. (2003): Walnut demonstrates strong genetics variability for adaptive and wood quality traits in a network of juvenile field tests across Europe. New Forests 25: 211-225.

Fernow, A. (2013): Laying the Groundwork for Association Mapping in Black Walnut (Juglans nigra L.).(https://pag. confex.com/pag/xxi/webprogram/Paper4910.html.)

Geyer, W. A., Rink, G. (1998): Interaction Effects of Seed Source, Culture, and Pest management on Growth of Juglan nigra in Plantations. Silvae Genet. 47 (19): 51- 58.

Kerr, G. (1993): Establishment and Provenance of Walnut in Britain. Forestry 66(4): 381-393.

Little, E. L. (Jr). (1971). Atlas of United States trees, volume 1, conifers and important hardwoods: U.S. Department of Agriculture Miscellaneous Publication 1146, 9 p., 200 maps. 
Michler, C. H., Woeste, K. E., Pijut, P. M. (2007): Black walnut. In: Kole, C. (ed) Forest trees. Genome mapping and molecular breeding in plants series, vol 7. SpringerVerlag, Berlin, pp 189-198

Pollegioni, P., Olimpieri, I., Woeste, K. E., De Simoni, G, Gras, M., Maria E., and Malvolti, M. E. (2013): Barriers to interspecific hybridization between Juglans nigra L. and Juglans regia L. species. Tree Genetics \& Genomes 9(1): 291-305.

Russell, K., Hemery, G. (2004): A New Tree Improvement Programme for black walnut in the United Kingdom. In: Michler, C.H.; Pijut, P.M.; Van Sambeek, J.; Coggeshall, M.; Seifert, J.; Woeste, K.; Overton, R.; Ponder, F., Jr., eds. 2004. Black walnut in a new century, proceedings of the 6th Walnut Council research symposium; 2004 July 25-28; Lafayette, IN. Gen. Tech. Rep. NC-243. St. Paul, MN: U.S. Department of Agriculture, Forest Service, North Central Research Station. 188 p.

Robichaud R.L., Glaubitz J. C., Olin E., Rhodes J., and Woeste K. (2006): A robust set of black walnut microsatellites for parentage and clonal identification. New For. 32: 179-196.

Reid, W. (1997): Evaluation and management of black walnut for nut production. In: Van Sambeek, J.W. (ed.): Knowledge for the future of black walnut: 5th Black walnut symposium; 1996 July 28-31; Springfield, MO. Gen.Tech.Rep.NC-191. St.Paul, MN: U.S. Department of Agriculture, Forest Service, North Central Forest Experiment Station: 211-216.

Reid, W., Coggeshall, M. V., Hunt, K. L. (2004): Cultivar evaluation and development for Black Walnut orchards. In: Michler, C.H.; Pijut, P.M.; Van Sambeek, J.; Coggeshall, M.; Seifert, J.; Woeste, K.; Overton, R.; Ponder, F., Jr., eds. 2004. Black walnut in a new century, proceedings of the 6th Walnut Council research symposium; 2004 July 25-28; Lafayette, IN. Gen. Tech. Rep. NC-243. St. Paul, MN: U.S. Department of Agriculture, Forest Service, North Central Research Station. $188 \mathrm{p}$

Robichaud, R. L., Glaubitz, J. C., Rhodes, O. E., Woeste, K. (2010): Genetic consequences of harvest in a mature second-growth stand of black walnut (Juglans nigra L.). Annals of forest science, 67(7): 702-702.

Stier, J. C. (1986): An initial assessment of (NC-99) forest tree improvement research in the North Central region. Unublished final report for project No. WO-14483. Cooperative Agreement 58-3159-4-29.73p.

Victory E., Glaubitz J.C., Olin E., Rhodes J., and Woeste, K. E. (2006): Genetic homogeneity in Juglans nigra (Juglandaceae) at nuclear microsatellites. Am. J. Bot. 93: 118-126.
Shifley, S. R. (2004): The black walnut resource in the United States. In: Michler, C.H.; Pijut, P.M.; Van Sambeek, J.; Coggeshall, M.; Seifert, J.; Woeste, K.; Overton, R.; Ponder, F., Jr., eds. 2004. Black walnut in a new century, proceedings of the 6th Walnut Council research symposium; 2004 July 25-28; Lafayette, IN. Gen. Tech. Rep. NC-243. St. Paul, MN: U.S. Department of Agriculture, Forest Service, North Central Research Station. 188 p.

Victory, E., Woeste, K., Rhodes, O. E. (JR). 2004: History of black walnut genetics in North America. In: Michler, C.H.; Pijut, P.M.; Van Sambeek, J.; Coggeshall, M.; Seifert, J.; Woeste, K.; Overton, R.; Ponder, F., Jr., eds. 2004. Black walnut in a new century, proceedings of the 6th Walnut Council research symposium; 2004 July 25-28; Lafayette, IN. Gen. Tech. Rep. NC-243. St. Paul, MN: U.S. Department of Agriculture, Forest Service, North Central Research Station. 188 p.

Victory, E. R., Glaubitz, J. C., Rhodes, O. E., Woeste, K. E. (2006): Genetic homogeneity in Juglans nigra (Juglandaceae) at nuclear micro- satellites. Am J Bot 93: 118-126.

Woeste, K., Burns, R., Rhodes, O., Michler, C. (2002): Thirty Polymorphic Nuclear Microsatellite Loci From Black Walnut. J. Hered. 93: 58-60.

Woeste, K., McKenna, J.R. (2004): Walnut genetic improvement at the start of a new century. In: Michler, C.H.; Pijut, P.M.; Van Sambeek, J.; Coggeshall, M.; Seifert, J.; Woeste, K.; Overton, R.; Ponder, F., Jr., eds. 2004. Black walnut in a new century, proceedings of the 6th Walnut Council research symposium; 2004 July 2528; Lafayette, IN. Gen. Tech. Rep. NC-243. St. Paul, MN: U.S. Department of Agriculture, Forest Service, North Central Research Station. 188 p. 


\title{
Larix kaempferi and Larix $x$ eurolepis
}

\author{
Georg von Wühlisch
}

Thünen Institut, Institut für Forstgenetik

Sieker Landstraße 2, 22927 Großhansdorf, Germany

\section{Distribution range}

\section{a. Natural distribution range}

Japanese larch (Larix kaempferi (Lamb.) Carr.) is native to the mountains of Chūbu and Kantō regions in central Honshū, Japan (Japan $35^{\circ}-37^{\circ} \mathrm{N}$., $137^{\circ}-140^{\circ}$ E., altitude $1,100-2,700 \mathrm{~m}$ a.s.l. average yearly precipitation 1,500 $-2,500 \mathrm{~mm}$, soils of volcanic origin). Here the species is naturally distributed on about 7,000 ha. According to this small natural range of less than $400 \mathrm{~km}$ maximum extension, the geographic differentiation is reduced and only negligible provenance differences were found.
Variation within hybrid larch (Larix $x$ eurolepis Henry) is mainly due to the different geographic origins of the European larch crossing partner.

\section{b. Distribution out of the species natural range}

Outside its native range, Japanese larch is naturalized on about 1.1 million ha in countries of the temperate zone with a coastal climate characterized by high precipitation and humidity. Japanese larch is valued for its fast growth on poor soils and exposed sites (e. g., polluted sites in the Ore mountains). In ideal conditions, the growth increment amounts to $13 \mathrm{~m}^{3}$ per ha at culmination age of about 35 years.



Figure 1. Natural distribution range of Japanese larch on Honshu Island, Japan. 


\section{Genetic Variation}

\section{a. Adaptive genetic variation}

As a consequence of the small distribution range the total variability of Japanese larch is low. The whole natural distribution area is considered one provenance (Schober and Rau 1991). However, the variability is sufficiently large for wood quality improvement and resistance breeding efforts (Kurinobu 2005). Also, stem form may vary between provenances (Quitt 2011).

The variability found in hybrid larch depends largely on the differences in the distribution areas of European larch (Pacque et al. 2013). The superiority of hybrid larch as compared to the parent species due to heterosis has been found unanimously in all studies published since the first discovery of fast-growing hybrid larch 1904 in Dunkeld, Scotland (Henry and Flood 1919, Schneck 2006, Schneck and Schneck 2007).

\section{Results of breeding efforts within the species natural range}

Improvement starts with plus tree selection followed by the establishment of seed orchards. Reproductive material in the form of seeds is produced in clonal seed orchards. It is used for operational reforestation as well as progeny testing (Kurinobu 2005).

\section{Results of breeding efforts in Europe}

Breeding efforts outside the natural range followed similar approaches as within the native range with the difference that plus tree selection were usually made in the introduced stands. In addition to the above, large efforts were focused on hybridizing Japanese and European larch and on testing the resulting progenies for the selection of suitable parents for hybridization purposes. Seed orchard designs are optimised to produce high proportions of hybrid seed (Schneck 2006; Schneck and Schneck 2007). Usually few clones of one of the two species are planted among a population of the other species. Those few clones are treated as mother trees that are then harvested to ensure high proportion of hybrid seed. As vegetative propagation of larch is difficult, grafting is used to produce the clones that are included in the clonal seed orchards.

\section{b. Neutral genetic variation}

Levels of genetic variation within and among natural populations of Japanese larch were evaluated by Tomaru (2009) by RFLP analysis of mtDNA obtained from 209 individuals representing 14 natural populations distributed across most of the species' natural range in central Japan. Distinctive polymorphism was only detected around the coxIII gene, following digestion with the EcoRI restriction enzyme, in the Southern hybridization analysis. Five haplotypes were identified across the 14 populations, with 11 populations exhibiting little or no genetic variation. Within-population genetic variation was low $(\mathrm{Hs}=$ $0.158)$, while population differentiation was substantial (a standardized genetic differentiation measure, Gst = 0.581). The northernmost, marginal population on Mt. Manokamidake made a significant contribution to the total detected genetic variation. The mtDNA variation displayed geographic structure despite the restricted natural distribution of Japanese larch (Tomaru 2009).

\section{Natural regeneration in Europe - genetic aspects}

Successful natural regeneration of Japanese larch occurs in the open with sufficient light and on bare soil devoid of vegetation. Therefore natural regeneration is practically negligible and the species non-invasive.

\section{References}

Henry A., Flood, M. G. (1919): The history of the Dunkeld hybrid larch Larix eurolepis, with notes on other hybrid conifers. Royal Irish Academy Proceedings 35, 5566.

Kurinobu, S (2005): Forest Tree Breeding for Japanese larch. Eurasian J. For. Res. 8-2: 127-134.

Schneck, V., Schneck, D. (2007): Testing of hybrid larch under different site conditions in Germany. In: Perron, M. (comp.): Integrated research activities for supply of improved larch to tree planting. Proceedings of the International Symposium of IUFRO Work. Gr. S2.02.07, Quebec, 2007, pp.97-100.

Schober, R., Rau, H.-M. (1991): Ergebnisse des I. Internationalen Japanlärchen-Provenienzversuchs. Schriften der Forstlichen Fakultät der Universität Göttingen und der Niedersächsischen Forstlichen Versuchsanstalt, Band 102.

Paques L. E., Foffová E., Heinze B., Lelu-Walter M.-A., Liesebach M., Philippe G. (2013): Chapter 2: Larches (Larix sp.). In: Paques LE (ed) Forest tree breeding in Europe: Current state-of-the-art and perspectives. Dordrecht, Heidelberg, London. Springer Verlag. 
Tomaru, N. (2009) Mitochondrial DNA variation in natural populations of Japanese larch (Larix kaempferi). Silvae Genet. 58(5/6): 234-241.

Quitt, S. (2011): Waldbauliche Behandlung von Japanlärchen / Buchen - Mischbeständen. http:// www.nw-fva.de/fileadmin/user_upload/Verwaltung/ Veranstaltungen/2011/--Quitt_S_Japanlaerche_Buche LOEWE 2011_Ankum.pdf 


\title{
Picea sitchensis
}

\author{
Georg von Wühlisch
}

\author{
Thünen Institut, Institut für Forstgenetik \\ Sieker Landstraße 2, 22927 Großhansdorf, Germany
}

\section{Distribution range}

\section{a. Natural distribution range}

Sitka spruce (Picea sitchensis (Bong.) Carr.) is native to the west coast of North America, with its northwestern limit on Kodiak Island, Alaska, and its southeastern limit near Fort Bragg in northern California (Griffin and Critchfield 1972). It is closely associated with the temperate rain forests and is found within a few kilometers of the coast in the southern part of its range. North of Oregon, its range extends inland along river floodplains, but nowhere does its range extend more than $80 \mathrm{~km}$ from the Pacific Ocean and its inlets. It covers $22^{\circ}$ of latitude and almost $3000 \mathrm{~km}$.
Picea sitchensis hybridizes freely with Picea glauca to form P. $\times$ lutzii, wherever the ranges of the two species overlap, such as along major river corridors across the British Columbia Coast Range and in coastal Alaska (Hamilton and Aitken 2013). In the Chilliwack River Valley of British Columbia, it occurs and hybridizes with Picea engelmannii. Hybridization between Picea sitchensis and the "interior spruce" (the Picea glauca $\times$ Picea engelmannii hybrid) has been reported in the Skeena River area of British Columbia (Sutton et al. 1994).

\section{b. Distribution out of the species natural range}

Outside its native range, the species is particularly valued for its fast growth on poor soils and exposed sites where few other trees can be grown successfully. In ideal

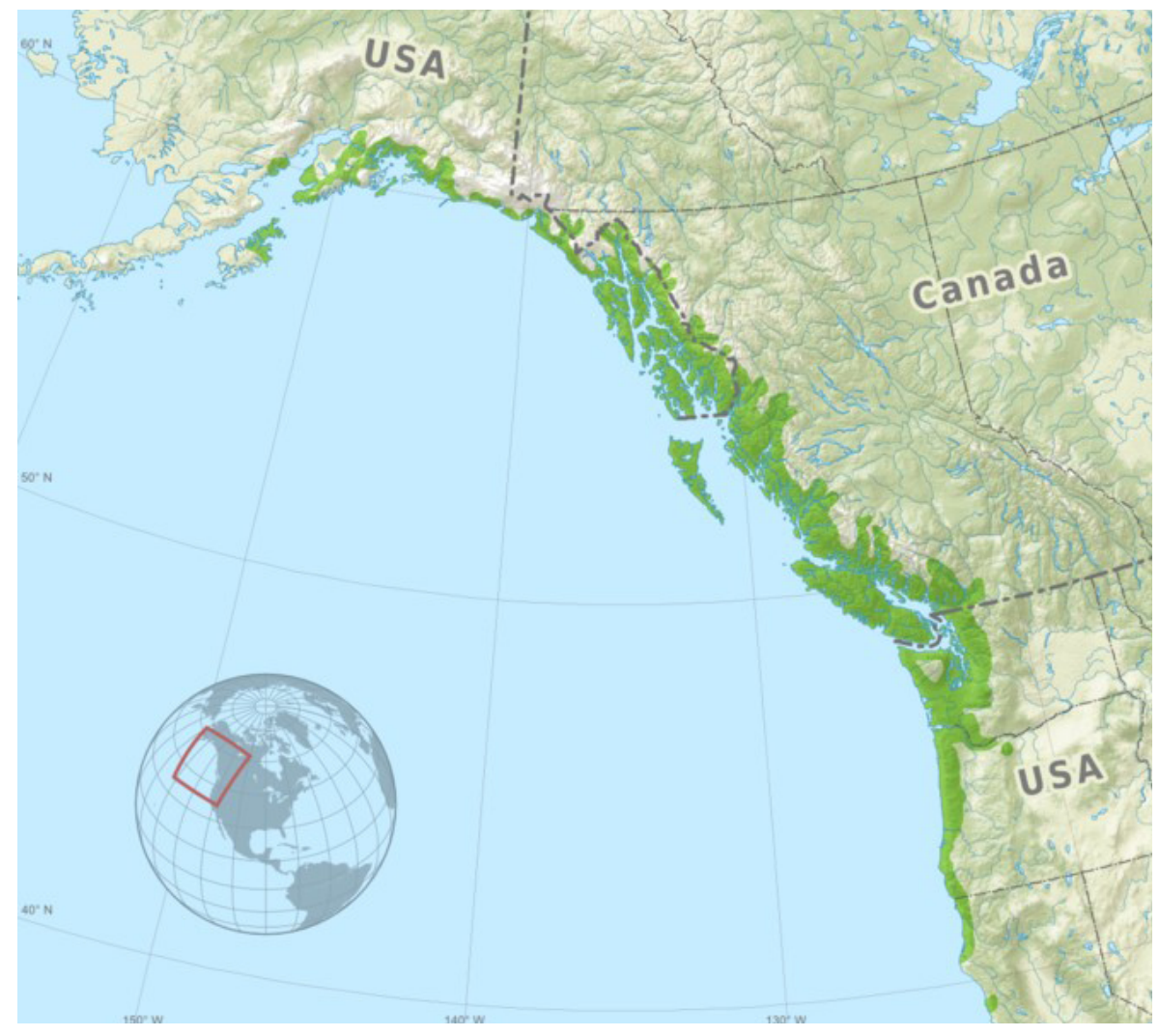

Figure1. Picea sitchensis distribution map (Source: A. Karnstedt Licence CC BY-SA 3.0 https://commons.wikimedia.org/wiki/File:Picea_sitchensis_distribution_map.png\#/media/File:Picea_sitchensis_distribution_map.png) 
conditions, young trees may grow $1.5 \mathrm{~m}$ per year in height. It is naturalized in parts of Ireland, Great Britain where it was introduced in 1831 (Mitchell 1978) as well as other European countries and New Zealand, though not so extensively as to be considered invasive.

There are now nearly 700,000 ha of Sitka spruce plantations established across Great Britain. The bulk of the Sitka spruce planting has been in Scotland (over $500,000 \mathrm{ha})$, but significant amounts $(80,000 \mathrm{ha})$ have been planted on suitable site types in each of England and Wales (Forestry Commission 2000). First rotation trees were raised in nurseries in Britain from seed imported from the Pacific North West. Origins from Washington State (USA) have been found to be well adapted to the warmer more autumn frost-free sites on the extreme west and south of Great Britain. Trees of Queen Charlotte Islands (British Columbia, Canada) origin are best adapted to the more commonly planted sites of northern England and to most of the Scotland sites (Samuel et al. 2007). An important trait is the susceptibility to autumn frost damage, a trait depending mainly upon the time of growth cessation, which can vary greatly among different Sitka spruce origins established in Great Britain; southern origins with inherently long vegetative periods are more susceptible (Mboyi and Lee 1999).

Sitka spruce is also planted extensively in Denmark, southwestern Norway, north-western France, southern Sweden and Iceland (Peterson et al. 1997). In Norway, Sitka spruce was introduced in the early 1900s. An estimated area of 50,000 ha has been planted in Norway, mainly along the coast from Vest-Agder in the south up to Troms in the north. It is more tolerant to wind and saline ocean air, and grows faster than the native Norway spruce. In Sweden Sitka spruce is being planted at an increasing rate and is considered as a species of great potential in the face of climate change.

\section{Genetic Variation}

\section{a. Adaptive genetic variation}

For cold hardiness, bud phenology and growth, the existence of clinal variation with latitude was detected (Mimura and Aitken 2007a). Holliday et al. (2008) studied the genetic control of cold hardiness and found significant among populations differential gene expression along the latitudinal range of Sitka spruce.

The species may suffer mainly from frost damage and it was revealed that site factors, particularly critical daylength or photoperiod, are important determinants of severity of autumn frost damage (Burley 1966), as they determine the onset of winter dormancy. Holliday et al. $(2010,2012)$ identified optimized combination of SNPs to predict adaptive phenotypes. They were able to explain around $30 \%$ of the phenotypic variation in autumn budset timing and cold hardiness each with five leading SNPs. The studies are important contributions to a comprehensive description of the genomic basis of adaptation for Sitka spruce.

\section{Results of breeding efforts within the species natural range}

One of the main objectives of the Sitka spruce breeding programs within the natural range is to develop, propagate, and deploy genotypes with robust resistance to the white pine weevil (Pissodes strobi Peck). The program is based on research that has been conducted on the extent and nature of genetic resistance of Sitka spruce populations to pine weevil in British Columbia. This research has international stature and provides a successful model for incorporating the results of research on natural genetic resistance to insect pests into applied breeding programs and proactive forest management (King and Alfaro 2009).

\section{Results of breeding efforts in Europe}

Being an important commercial species in Ireland and Great Britain it is there where the most progress has been made in the area of selection and breeding (Lee and Connolly 2010). The greatest effort and progress has been made with Sitka spruce for which volume gains of improved planting stocks and rotation age have been predicted to be between 21\% and 29\% (Lee and Matthews, 2004).

Improved Sitka spruce planting stock is now widely planted in Britain and the breeding programme for the species is now advancing to the second generation. Nearly 26 million ( 80 per cent) of the 32 million Sitka spruce trees planted in 2007 were from improved stock (Forestry Commission, 2009). Home-produced supply of improved stock almost meets planting demand preventing a need to return to the Pacific North West for seed. Progenytested clonal seed orchards established throughout the 1980s now give substantial harvests of seed at intervals of 3-4 years. Vegetatively propagated family mixtures, originating from the artificial control pollination or open pollination among top-ranked plus-trees growing in seed orchards (production populations), are currently produced. In order though to satisfy customer specific requirements, the production of a number of alternative production populations is planned in order to produce control-pollinated family mixtures, with an increased weighting and genetic gain on traits of interest, including 
also stem straightness or wood density, which will then be vegetatively propagated and made available to the market (http://www.forestry.gov.uk/fr/ggae-548g6t).

More limited selection and breeding work has been carried out in some other European countries where this species is of secondary or minor significance like Denmark, France, Germany, and Norway.

\section{b. Neutral genetic variation}

The hybridization among spruce species in some parts of the natural range distribution was from the beginning in the focus of genetic investigations. First isozymes were successfully used for species distinction (Copes and Beckwith 1977, Yeh and Arnott, 1986). Later on species specific microsatellites (Rajora et al. 2001, Bennuah et al. 2004) and SNPs (Hamilton et al. 2013) were identified and used to study introgression zones and processes.

Total genomic DNA was studied by Gapare et al. (2005). The genetic diversity, as measured by expected heterozygosity between core populations (mean $\mathrm{H}_{\mathrm{E}}=$ 0.58 ) and peripheral populations (mean $\mathrm{H}_{\mathrm{E}}=0.56$ ) was found to be similar. However, there was significant inbreeding in peripheral $\left(\mathrm{F}_{I S}=0.17\right)$ but not in core $\left(\mathrm{F}_{I S}=\right.$ $0.03)$ populations. Large differences in gene flow estimates were observed between core $\left(\mathrm{N}_{\mathrm{m}}=9.0\right)$ and peripheral populations $\left(\mathrm{N}_{\mathrm{m}}=3.5\right)$.

Mimura and Aitken (2007a) indicated strong correlation between geographic and genetic distances between populations which was statistically significant. Allelic richness and gene diversity was higher in central and lower in the isolated peripheral populations. Also more private alleles were found in the central and continuous populations. Central and peripheral populations differ in mating system parameters. The estimated effective number of pollen donors was much higher in the center of the range $($ mean $=18.5)$ than at the periphery $($ mean=3.6), while selfing rate increased from $7.3 \%$ in central populations to as high as $35.2 \%$ in the northern, isolated population (Mimura and Aitken, 2007b).

cpDNA does not reveal genetic variation for Sitka spruce. The reason could be the high pollen flow across the species wide range (Soltis et al. 1997).

\section{Natural regeneration in Europe - genetic aspects}

Natural regeneration of Sitka spruce is potentially profuse, however, its success depends on the condition of the mother stands, soil conditions, human influences etc. In plantation forestry of Ireland and Great Britain, improved reproductive material is mostly used, since it generally guarantees significantly higher productivity. Despite its natural regenerative power Sitka spruce is not found to be invasive.

\section{References}

Bennuah, S. Y., Wang, T., Aitken, S.N. (2004): Genetic analysis of the Picea sitchensis $\mathrm{x}$ glauca introgression zone in British Columbia. Forest Ecology and Management 197: 65-77.

Burley, J. (1966): Genetic Variation in Seedling Development of Sitka Spruce, Picea sitchensis (Bong). Carr. Forestry 39: 68-94.

Copes, D. L., Beckwith, R. C. (1977): Isoenzyme identification of Picea glauca, P. sitchensis, and P. lutzii populations. Bot.G.Az. 138(4): 512-521.

Forestry Commission (2000) : Respacing naturally regenerating Sitka spruce and other conifers. Practice note; Edinburgh (http://www.forestry.gov.uk/pdf/FCPN016. pdf/\$FILE/FCPN016.pdf).

Forestry Commission (2009): Predicted Gains from Sitka Spruce Parents of Families (Family Mixtures). Edinburgh (http://www.forestry.gov.uk/fr/INFD-6JUL3Z).

Gapare W. J., Aitken S. N., Ritland C. E. (2005): Genetic diversity of core and peripheral Sitka spruce (Picea sitchensis (Bong Carr)) populations: implications for conservation of widespread species. Biol. Conserv. 123: 113-123.

Griffin, J. R., Critchfield, W. B. (1972): The distribution of forest trees in California. Res. Paper PSW-RP-82. Berkeley, CA: Pacific Southwest Forest and Range Experiment Station, Forest Service, U.S. Department of Agriculture; $60 \mathrm{p}$.

Hamilton, J. A., Aitken, S.N. (2013a): Genetic and morphological structure of a spruce hybrid (Picea sitchensis $\times$ P. glauca) zone along a climatic gradient. American Journal of Botany 100(8): 1651-1662.

Hamilton, J. A., Lexer, C., Aitken, S. N. (2013b): Genomic and phenotypic architecture of a spruce hybrid zone (Picea sitchensis x P. glauca) Molecular Ecology 22: 827-841 DOI: 10.1111/mec.12007.

Hamilton, J. A., Ralph, S. G., White, R., Bohlmann, J., Aitken, S. N. (2008): Global monitoring of autumn gene expression within and among phenotypically divergent populations of Sitka spruce (Picea sitchensis). New Phytologist 178: 103-122. 
Holliday, J. A., Kermit, R., Aitken, S. N. (2010): Widespread, ecologically relevant genetic markers developed from association mapping of climate-related traits in Sitka spruce (Picea sitchensis). New Phytologist 188: 501-514 (doi: 10.1111/j.1469-8137.2010.03380.x).

Holliday, J. A., Wang, T., Aitken, S. (2012): Predicting Adaptive Phenotypes From Multilocus Genotypes in Sitka Spruce (Picea sitchensis) Using Random Forest. G3 Genes/ Genomes/Genetics. 2:: 1085-1093. DOI: 10.1534/ g3.112.002733.

King, J. N., Alfaro, R. I. (2009): Developing Sitka spruce populations for resistance to the white pine weevil: summary of research and breeding program. B.C. Min. For. Range, For.Sci. Prog., Victoria, B.C. Tech. Rep. 050.

Lee, S. J., Matthews, R. (2004): An indication of the likely volume gains from improved Sitka spruce planting stock. Forestry Commission Information Note 55. Forestry Commission, Edinburgh.

Lee, S. J., Connolly, T. (2010): Finalizing the selection of parents for the Sitka spruce (Picea sitchensis (Bong.) Carr) breeding population in Britain using Mixed Model Analysis. Forestry, DOI:10.1093/forestry/cpq024.

Mimura, M., Aitken, S. N. (2007a): Adaptive gradients and isolation-by-distance with postglacial migration in Picea sitchensis. Heredity 99: 224-232.

Mimura, M., Aitken, S. N. (2007b): Increased selfing and decreased effective pollen donor number in peripheral relative to central populations in Picea sitchensis (Pinaceae). American Journal of Botany 94(6): 991-998.

Mitchell, A. (1978): Trees of Britain \& Northern Europe. Collins Field Guide. Harper Collins. London. ISBN 0-00-219213-6.

Mboyi, W. M., Lee, S. J. (1999): Incidence of autumn frost damage and lammas growth in a 4-year-old clonal trial of Sitka spruce (Picea sitchensis) in Britain. Forestry 72(2): 135-146.

Peterson, E. B., Peterson, N. M., Weetman, G. F., Martin, P. J. (1997): Ecology and management of Sitka spruce, emphasizing its natural range in British Columbia. UBC Press, Vancouver, British Columbia, Canada.

Rajora, O. P., Rahmann, M. H., Dayanandan, S., Mosseler, A. (2001): Isolation, characterization , inheritance and linkage of microsatellite DNA Markers in white spruce (Picea glauca) and their usefulness in other spruce species: Mol Gen Genet 264:871-882. DOI $10.1007 / \mathrm{s} 004380000377$.
Samuel, C. J. A., Fletcher, A. M., Lines, R. (2007): Choices of Sitka spruce origins for use in British forests. Forestry Commission Bulletin No. 127. Forestry Commission, Edinburgh; 112 p.

Soltis, D. E., Gitzendanner, M. A., Strenge, D. D., Soltis, P. S. (1997): Chloroplast DNA intraspecific phylogeography of plants from the Pacific Northwest of North America. Plant. Syst. Evol. 206: 353-373.

Sutton, B. C. S., Pritchard, S. C., Gawley, J. R., Newton, C. H., Kiss, G. H. (1994): Analysis of Sitka spruceinterior spruce introgression in British Columbia using cytoplasmic and nuclear DNA probes. Canadian Journal of Forest Research 24(2): 278-285.

Yeh, F. C., Arnott, J. T. (1986): Electrophoretical and morphological differentiation of Picea sitchesis, Picea glauca and their hybrids. Canadian Journal of Forest Research, Vol. 16: 791-718. 


\title{
Pinus contorta
}

\author{
Bo Karlsson ${ }^{1}$ and Johan Kroon ${ }^{2}$
}

${ }^{1}$ Skogforsk, Ekebo 2250, 26890 Svalov, Sweden, ${ }^{2}$ Skogforsk, Tomterna 1, 91821 Sävar, Sweden

\section{Distribution range}

\section{a. Natural distribution range}

Pinus contorta Dougl. ex. Loud. (Lodgepole pine) has its main distribution range in Western North America with a wide latitudinal and elevational range. Lodgepole pine is one of the most widely distributed tree species in western North America, extending from Alaska south to Mexico and east to South Dakota (Figure 1). It grows throughout the Rocky Mountain and Pacific regions, with a range extending from approximately $31^{\circ} \mathrm{N}$ in Baja California north to around $64^{\circ} \mathrm{N}$ in the Yukon Territory, and from the Pacific Ocean east to South Dakota (OECD 2008).

Forests dominated by lodgepole pine cover approximately 26 million ha. The majority of this area is in Canada (20

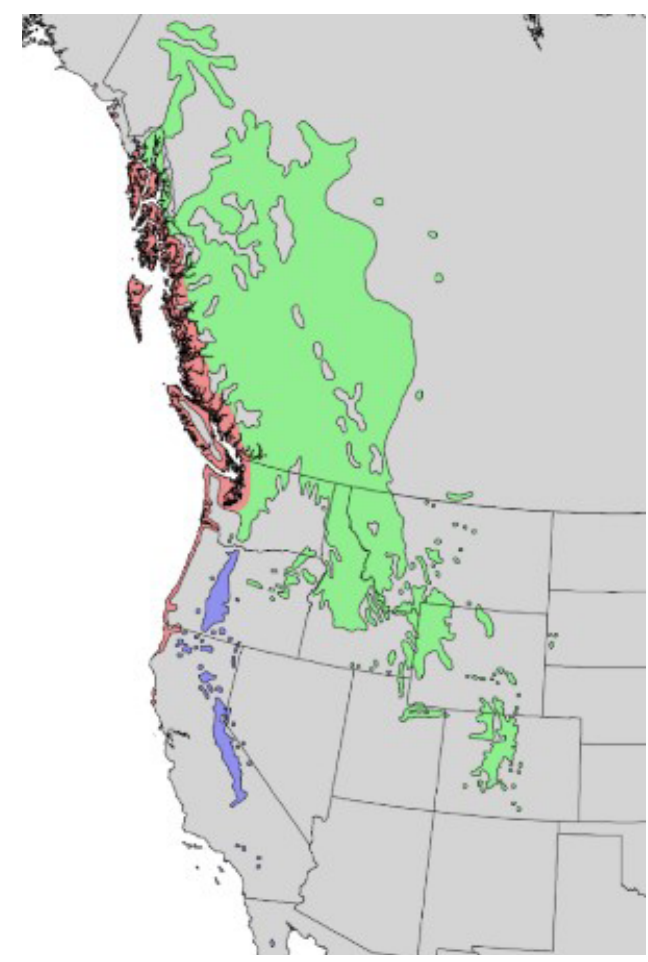

Figure 1. Distribution map: Pinus contorta subsp. contorta Pinus contorta subsp. latifolia Pinus contorta subsp. murrayana. Based on Little (1971) million ha) and is dominated by the Rocky Mountain lodgepole pine (subsp. latifolia, Interior). Lodgepole pine hybridizes with Jack pine (Pinus banksiana). Pinus contorta includes 4 distinctly different varieties out of which the most important is Rocky Mountain lodgepole pine (Pinus contorta var. latifolia). The other three are Shore pine (Pinus contorta var. contorta), Sierra lodgepole pine (Pinus contorta var. murrayana), and Bolander pine (Pinus contorta var. bolanderi). The varieties differ in tree longevity, dimensions, form, branchiness, needle size and structure and cone form.

During the last decade Interior lodgepole pine in British Columbia has been decimated by the largest recorded attacks of mountain pine beetle (Dendroctonus ponderosae) with over 10 million hectares currently affected.

\section{Genetic Variation}

\section{a. Adaptive genetic variation}

\section{Results of breeding efforts within the species natural range}

Range-wide and regional geographical variation has been studied in detail through provenance and provenanceprogeny tests in British Columbia (BC). One test series consisting of 140 provenances planted in 1974 was spread over 60 sites in 11 eco-regions. Another series consisted of 778 OP-families from 53 provenances. The results after 20 years showed that site and origin were the most significant factors for growth traits. There was a significant provenance by site interaction but the variance component was rather small. Tree height was significantly related to geographic origin (lat. - long. elev.). Provenance variation in pest resistance was also strongly related to geographic origin. A geographic cline was detected from southwest to northeast in BC with a steep west-east long incline (the farther western site - the less optimality of the local population). The elevational cline was much less steep, 
but showed that the higher the elevation of the site, the less the optimality of the local population. Mean annual temperature and mean temperature of the coldest month were the best predictors of provenance height, while the ratio summer temperature/summer moisture was the best predictor for provenance survival.

Results from provenance tests in Alberta showed that high elevation provenances and provenances of high latitude performed worse in terms of growth.

Insect and disease resistance for a variety of pests including western gall rust (Endocronartium harknessii), stalactiform blister rust (Cronartium coleosporioides), needle cast (Lophodermella concolor) and Sequoia pitch moth (Synanthedon sequoiae) varies significantly among provenances and increases with proximity to the natural range of Pinus banksiana (jack pine), indicating that introgression may provide genetic variation for pest defenses to Pinus contorta (Wu et al. 1996).

A total of 158 seed lots were distributed around the world for International Union of Forest Research Organizations (IUFRO) provenance trials (summarized in Lindgren 1993), but most of these trials contain only a subset of provenances from a limited geographic area.

Breeding programmes for lodgepole pine within the natural range are currently running in the territories of British Columbia and Alberta, where it is one of the most important species for reforestation.

In British Columbia, seven seed planning (breeding) zones are recognized. The traits used in the breeding programme has been growth, with restrictions on wood density loss, and some disease resistance traits. Future breeding objectives may shift to more emphasis on resistance, climate change, adaption and forest health. Due to the intensive reforestation programme after the mountain pine beetle (Dendroctonus ponderosae) the lodgepole pine seed orchard capacity has been greatly expanded. A total of
35,000 ramets have been grafted and 8 new seed orchards planted. Genetic variation for resistance to mountain pine beetle attack has been documented in a first generation progeny test series.

Seed transfer guidelines of lodgepole pine have been updated according to cumulative provenance testing results. Transfer of natural seed sources will depend on both geographic and climatic differences between the source and planting locations. Seed planning zones are realigned to improve overlay between genetic patterns of geographic variation and biogeoclimatic classification, and to minimize negative impacts associated with predicted climate change over the rotation.

In Alberta, there are five breeding zones with a total of approximately 1,100 phenotypically selected parent trees. The focus is among other things, on improving climate change adaptation. Another issue is to collect and store seeds to capture the gene pool of the species before these stands are killed by the mountain pine beetle. Several Alberta forest companies have their own tree improvement programmes alone or in cooperation with others. The programmes are linked to the Alberta Forest Genetic Resources Council, functioning as an advisory body for management of Alberta’s forest genetic resources.

In Idaho and Montana, the Inland Empire Tree Improvement Cooperative has had an ongoing breeding program since 1978 .

\section{Results of breeding efforts in Europe}

The introduction of lodgepole pine in Sweden was accompanied by broad research and extensive collections of seed samples in order to improve the knowledge base and refine the choice of seed sources (Table 1). A summary of experiences from the introduction phase have been summarized in an official evaluation document from the Swedish Forest Agency (Skogsstyrelsen 1992) as well as in many other research reports (Elfving et al. 2001, Lindgren

Table 1. Overview of the Swedish introduction of Lodgepole pine.

\begin{tabular}{|l|l|}
\hline 1910 & First experience with Lodgepole Pine \\
\hline 1920 & Practical tests \\
\hline 1940 & First provenance tests are put out \\
\hline 1950 & More practical experiment is put out \\
\hline 1960 & $\begin{array}{l}\text { Establishment of systematic provenance tests. First plus-tree selection is initiated by the two most progres- } \\
\text { sive forest companies }\end{array}$ \\
\hline 1970 & Second plus tree selection and a broad scale introduction starts \\
\hline 1980 & $\begin{array}{l}\text { Promising result in young plantations and trials. Some years with extreme weather conditions show high } \\
\text { rates of infection by Gremmeniella abietina, uncertainty about future problems limits reforestation with } \\
\text { lodgepole pine }\end{array}$ \\
\hline 1990 & The environmental debate concerning forestry affects the possible use of lodgepole pine \\
\hline 2000 & $\begin{array}{l}\text { The earlier laborious planting of lodgepole pine now start to show results in management and early harvest } \\
\text { operations. Questions of how to increase wood production turn interest to lodgepole pine again }\end{array}$ \\
\hline
\end{tabular}


et al. 1993). A large-scale introduction of lodgepole pine in Sweden started around 1970 and was accompanied by thorough collections of seed material and comprehensive research. Simultaneously, seed orchards and a domestic breeding base for future needs were established.

Both companies and institutions established many provenance trials in the period from 1962 to 1979. These trials covered all of Sweden (Figure 2) in order to form a basis for seed transfer recommendations. Early experiments indicated that provenances originating from interior British Columbia and from the Yukon Territory performed best. It was discovered that a $2-5^{\circ}$ northern transfer (depending on the site latitude) into Sweden seemed to be optimal (Lindgren et al. 1988). The provenance test results guided the plus-tree selection, which was initiated in the 1970's to make Sweden selfsupporting with genetically good LP base material and seed sources. The program included plus tree selection in Canada (Figure 3), genetic testing of open-pollinated families in field tests in Sweden, and establishment of six seedling seed orchards for genetic rouging.

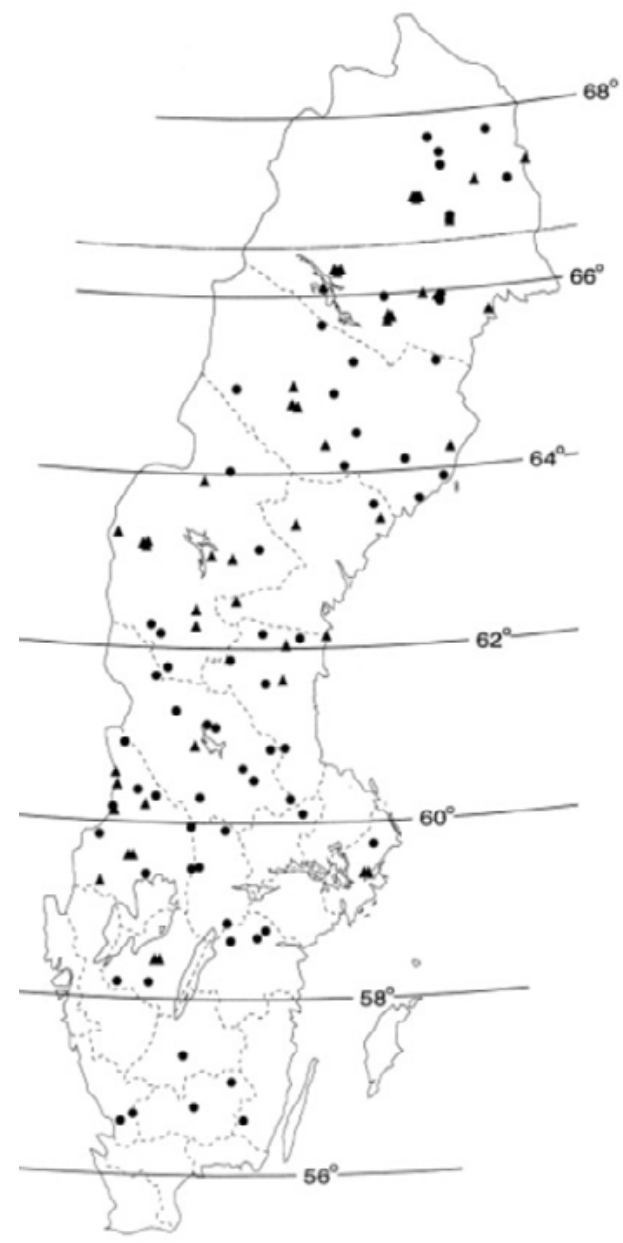

Figure 2. Provenance trials with lodgepole pine (LP) in Sweden established up until 1970 (triangles; first in 1962) and from 1971 on (circles; last in 1979). (Elfving et al. 2001)

\section{b. Neutral genetic variation}

Results from allozyme studies show that there is very little differentiation between sub-species as well as between populations within subspecies (Wheeler and Guries 1982).

Marginal (disjunct or peripheral) populations show a higher degree of population differentiation than core populations, presumably due to reduced gene flow (Fazekas and Yeh 2001; Yeh and Layton 1979). Populations separated by short distances (one or two $\mathrm{km}$ ) differ very little genetically (Knowles 1984).

Expected heterozygosities for microsatellite markers (SSR, single sequence repeats) range from 0.67 to 0.77 and 0.39 to 0.47 for RAPD (randomly amplified polymorphic DNA) (Thomas et al. $\left.{ }^{\circ} 1999\right)$. For both types of markers, over $94 \%$ of variation was found within populations. Planted stands did not differ significantly from naturally regenerated stands for expected heterozygosity.



Figure 3. Provenance groups from the plus tree selection for the Swedish breeding programme. 


\section{Natural regeneration in Europe}

Lodgepole pine is already by far the most planted nonnative tree species in Swedish forests. An important review of the Swedish introduction and the ecological consequences of lodgepole pine in Sweden was done in the Environmental impact analysis (EIA) (Engelmark et al. 2001). The social and ecological aspects have been in focus lately and reported by the Swedish Forest Stewardship (Widenfalk 2015).

Dispersal of sufficient seed to adequately restock an area often only occurs within $60 \mathrm{~m}$ of the seed source. The annual seed-fall from the non-serotinous cones of initial colonizers helps to fully occupy sites. Broadcast burning can be used to accelerate the release of seeds from such cones or from those with limited exposure to sunlight. Some seeds will be destroyed; however, the amount will vary with fire intensity.

In Sweden it was thought that the natural generation of lodgepole pine was low or non-existent due to good forest fire control. Later assessments show that natural regeneration is fairly common and the seeds can spread in rather long distances. The amount of natural regeneration and the rate of invasiveness is the target of a recently established study. In a longer perspective it is likely that the frequency of genotypes with non-serotinous cones will increase due to selection.

Seeds from planted stands are used mostly for direct seeding in the forest. For plant production seed orchard seeds from the Swedish breeding programme is preferred.

\section{References}

Elfving, B., Ericsson, T. Rosvall, O. (2001): The introduction of lodgepole pine for wood production in Sweden - a review. Forest Ecol. Manag. 141: 15-29.

Engelmark, O., Sjöberg, K., Andersson, B., Rosvall, O., Ågren, G. I., Baker, W. L., Barklund, P., Björkman, C., Despain, D. G., Elfving, B., Ennos, R. A., Karlman, M., Knecht, M. F., Knight, D. H., Ledgard, N. J., Lindelöw, Å., Nilsson, C., Peterken, G. F., Sörlin, S., Sykes, M. T. (2001): Ecological effects and management aspects of an exotic tree species: the case of lodgepole pine in Sweden. Forest Ecology and Management 141: 3-13.
Fazekas, A. J., Yeh, F. C. (2001): Random amplified polymorphic DNA diversity of marginal and central populations in Pinus contorta ssp. latifolia. Genome 44: 1322.

Knowles, P. (1984): Genetic variability among and within closely spaced populations of lodgepole pine. Canadian Journal of Genetics and Cytology 26: 177-184.

Lindgren, K. (1993): IUFRO Pinus contorta seed collections: Distribution and publications. In: D. Lindgren(ed.), Proceedings of Pinus contorta - From untamed forest to domesticated crop. Meeting ofIUFRO WP 2.02.06 and Frans Kempe Symposium, Umeå, August 24-28, 1992. Swedish Universityof Agricultural Sciences, Report 11: 232-237.

Lindgren, K., Lindgren, D., Rosvall, O. (1988): Förflyttningsrekommendationer för provenienser av contortatall i Sverige [Lodgepole pine provenance transfer recommendations for Sweden] (Arbetsrapport nr 27, Inst. för skoglig genetik och vaxtfysiologi, SLU), 43 pp. Umeå. (In Swedish)

Lindgren, D., Lindgren, K., Krutzsch, P. (1993): Use of lodgepole pine and its provenances in Sweden. In: Lindgren, D. (Ed.) Crop, Pinus contorta from untamed forests to domesticated Kempe, Proceedings of the IUFRO meeting and Frans Breeding., Symposium 1992 on Pinus contorta provenances and Report 11, Department of Forest Genetics and Plant Physiology Sw. 238-263.

Little, E. L., Jr. (1971): Atlas of United States trees, volume 1, conifers and important hardwoods: U.S. Department of Agriculture Miscellaneous Publication 1146, 9 p., 200 maps.

OECD (2008): Consensus Document on the Biology of Lodgepole Pine (Pinus contorta Dougl. ex. Loud.). OECD Environment, Health and Safety Publications. Series on Harmonisation of Regulatory Oversight in Biotechnology, 32(44), pp.1-16. http://www.oecd.org/ officialdocuments/displaydocumentpdf?cote $=e n v / j m /$ mono(2010) $46 \&$ doclanguage $=$ en .

Skogsstyrelsen (1992): Contortatallen i Sverige - en lägesrapport. Skogsstyrelsen. 
Thomas, B. R., Macdonald, S. E., Hicks, M., Adams, D. L., Hodgetts, R. B. (1999): Effects of reforestation methods on genetic diversity of lodgepole pine: An assessment using microsatellite and randomly amplified polymorphic DNA markers. Theoretical and Applied Genetics 98: 793-801.

Widenfalk, O. (2015): Contortatall i Sverige - En kunskapssammanställning och riskbedömning. Rapport Svenska FSC, p.24. ATISC 2007 Controlled parentage program for the region J Lodgepole pine improvement project in the northwest boreal region of Alberta. Technical report 07-11. Alberta Tree Improvement and Seed Centre. $30 \mathrm{pp}$

Wheeler, N. C., Guries, R. P. (1982): Population structure, genetic diversity, and morphological variation in Pinus contorta Dougl. Canadian Journal of Forest Research 12: 595-606.

Wu, H. X., Ying, C. C., Muir, J. A. (1996): Effect of geographic variation and jack pine introgression ondisease and insect resistance in lodgepole pine. Canadian Journal of Forest Research 26: 711-726.

Yeh, F. C., Layton, C. (1979): The organization of genetic variability in central and marginal populations of lodgepole pine Pinus contorta ssp. latifolia. Canadian Journal of Genetics and Cytology 21: 487-503.

http://www.fs.fed.us/database/feis/plants/tree/pinconl/all. html\#GENERAL DISTRIBUTION

http://aep.alberta.ca/lands-forests/forest-health/treeimprovement-and-adaptation.aspx

http://www.abtreegene.com/

https://www.for.gov.bc.ca/hre/forgen/interior/pine. $\underline{\mathrm{htm} \# 1)}$ 


\title{
Pinus strobus
}

\author{
Paraskevi Alizoti \\ Aristotle University of Thessalonniki , Faculty of Forestry and Natural Environment, \\ 54124 Thessaloniki, Greece
}

\section{Natural distribution range}

Pinusstrobus L. (Eastern white pine) is naturally distributed in eastern North America: from Newfoundland to northern Georgia and westward to Manitoba and Minnesota. The species is represented in the United States by the typical variety, Pinus strobus var. strobus. Pinus strobus var. chiapensis has a restricted distribution and is native in the mountains of southern Mexico and Guatemala (Wendel and Smith 1990), but the populations are threatened by deforestation and targeted logging.

The species grows in cool and humid regions, can withstand frost depth more than $178 \mathrm{~cm}$, and average annual snowfall from $13-254 \mathrm{~cm}$. It can grow in a broad variety of soils, ranging from sandy (where is a strong competitor) to sandy loams, slit-loams, clay soils and poorly to very poorly drained soils (Wendel 1980, Mader 1985, Wendel and Smith 1990). It forms pure and mixed forests and can function as a pioneer species, but also as a climax species on dry and sandy soils.

Pinus strobus may hybridize readily with native and exotic to North America pines such as: Pinus monticola, Pinus peuce, Pinus griffithii, Pinus parviflora, Pinus flexilis and Pinus ayacahuite.

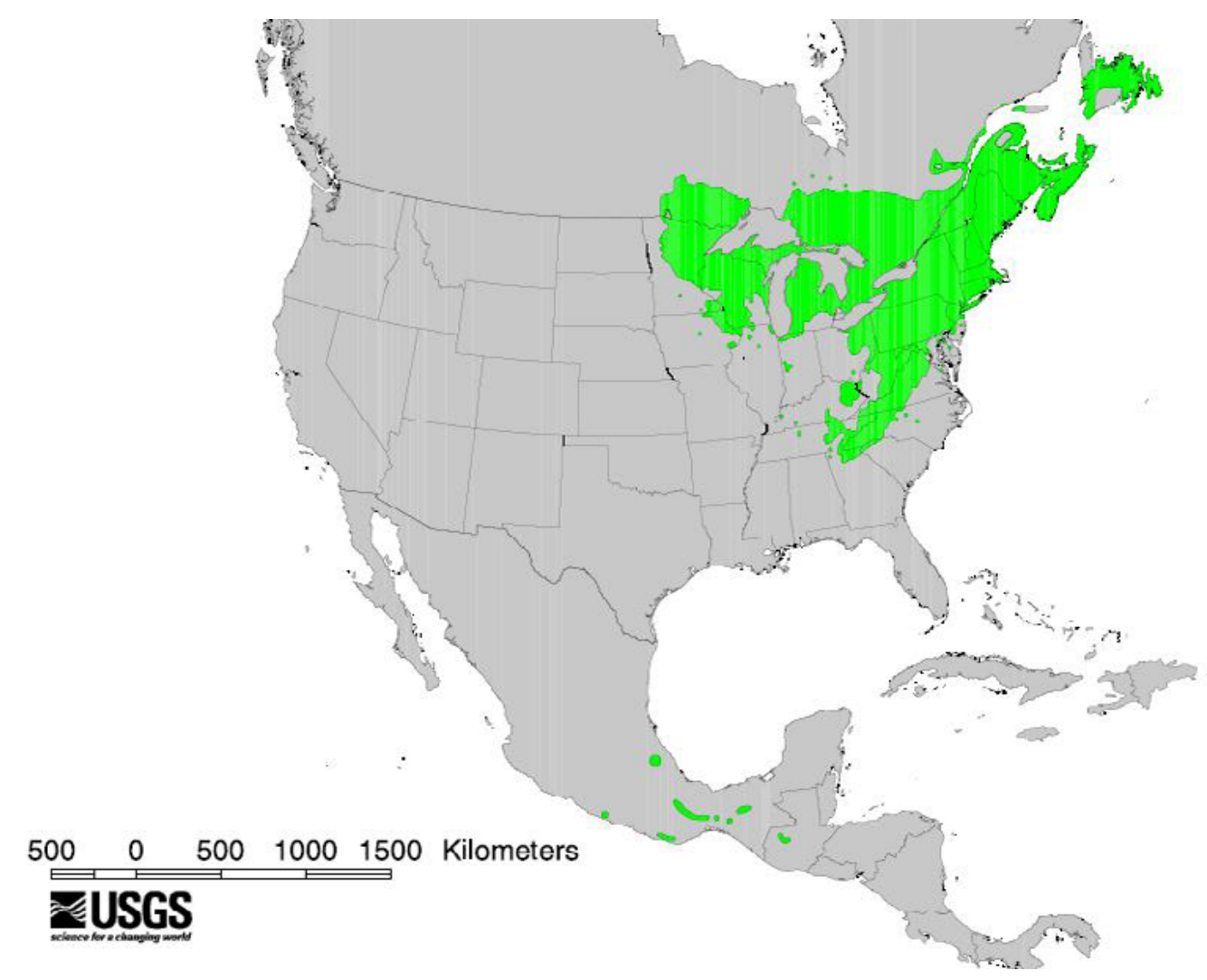

Figure 1. Natural distribution range of Pinus strobus. (Adopted from : http://www. usgs.gov/ - Based on Little, E.L., Jr., 1971). 


\section{Genetic variation}

\section{a. Adaptive genetic variation}

\section{Results of breeding efforts within the species natural range}

Extensive range-wide provenance testing in North America has demonstrated that Pinus strobus is a highly variable species for growth traits that retains also its capacity to adapt to a broad range of environmental conditions (Fowler 1965, Wright 1970). Test trials demonstrated that, at middle latitudes, the provenances of western North Carolina, Tennessee and northern Georgia outperformed by $80 \%$ all other provenances in height growth. These provenances exhibited the same growth superiority when introduced and tested in provenance trials established in Australia and New Zealand. Follow up trials focused mainly on southern Appalachian provenances reconfirmed the superiority of growth of the seed sources from North Carolina, Tennessee and Georgia (Wright et al. 1979).

Heritability for growth traits ranges from 0.28 to 0.54 , resulting in a genetic gain of $22 \%$ in volume, after selection in first generation progeny tests as reported by Kriebel (1978), and Thor and Gall (1978).

Even though breeding has succeeded a significant genetic gain for growth rate, it hasn't reached the same level of success in producing genetic material resistant to the insect Pissodes strobi (Peck) (white pine weevil) and the fungus Cronartium ribicola (white pine blister rust) which cause heavy damages in trees originating from all seed sources of the species (Garrett, 1972). However, few provenances exhibited low susceptibility to repeated weevil attacks and thus, selection of tolerant phenotypes within the stands of those provenances can be the initial step for new breeding programmes (Genys 1981, Wilkinson 1981). Resistance for white pine blister rust is considered to be polygenic and long lasting breeding efforts are required to produce resistant genetically improved material (Heimburger 1972). Pinus strobus has been proven to be sensitive to the co-existence and interaction of $\mathrm{SO}_{2}$ and $\mathrm{O}_{3}$, exhibiting though a vast amount of genetic variation on an individual tree basis, regarding the level of susceptibility to these pollutants (Houston and Stairs, 1979). Natural selection eliminated the susceptible to pollution individuals in the wild and in breeding populations resulting in shrinkage of the gene pool, as only tolerant trees survived and produced seed. Progenies from the above populations though were almost $100 \%$ tolerant to the pollutants and retained the vigour of the parental populations or stands (Kriebel and Leben, 1981).

Pinus strobus can successfully withstand inbreeding.
Recording of managed and unmanaged populations indicated that inbreeding may be a natural characteristic of the species (Fowler 1965, Echt 2000). Self-pollination of selected genotypes in Ohio did not result in reduction of their seed yield, while the reduction of growth of the inbred progenies ranged among $18 \%$ to $38 \%$ when compared to outcrossed progenies, depending upon the site (Kriebel 1982).

In a hybridization program aiming towards improving growth, survival and wood specific gravity, Pinus strobus was crossed with Pinus wallichiana and Pinus monticola. The hybridization among species resulted in selection of hybrid families that outperformed all others (Kriebel 2004). To improve resistance to white pine weevil Pinus strobus was crossed with the resistant Pinus peuce (used as male parent), and the hybrids were backcrossed with Pinus strobus to improve growth rate (Kriebel 2004). The second potential species for hybridization was Pinus monticola, but in this case, instead of using hybrids, the planting of Pinus monticola could be preferred as it is more weevil resistant than Pinus strobus and can grow in the eastern United States (Heimburger 1972).

\section{Results of breeding efforts in Europe}

Pinus strobus was among the first five-needle pines introduced in Europe. Its first occurrence was reported in the Royal Gardens of Fontainebleau in France in 1553. Then it was introduced in Great Britain in 1957 and Germany in 1770 (Blada and Popescu 2004). The species proved to be well adapted to the European climatic conditions and was introduced in almost all European countries, where it was planted mainly for timber production (Blada and Popescu 2004).

The first two provenance trials were established in Germany in 1966-1967 and 69 provenances originating from the natural range of the species were tested (Stephan 1974). Results of those trials, 30 years after planting, showed that the southern provenances from the Appalachians are of particular interest, as they exhibited adaptation to climatic and other environmental conditions, but were susceptible to blister rust (Stephan, 2004). Provenance testing was also carried out in Croatia and included six North American provenances and four seed lots of unknown origin collected from plantations previously established in the country (Orlic 1993). Results at the age of eighteen indicated that two of the seed lots originating from the previous plantations in Croatia outperformed the introduced provenances for survival and height growth, while the provenance from Georgia exhibited the higher diameter growth. In Romania, a nursery provenance test was established for the species testing 45 provenances (Radu 1974). Nineteen provenances from North America were tested together with twenty six provenances of 
unknown origin. The seed was collected from old planted stands of the species across Europe. It was found that the Minnesota provenances were slow growing but had the highest dry matter content, while the faster growing provenances from North Carolina, Kentucky and Ohio had the lowest dry matter content at the seedling stage.

Interspecific hybridization among Pinus strobus and Pinus peuce, as well as among Pinus strobus and Pinus wallichiana was also carried out in Romania. The hybridization program included inter- and intra- specific hybridization and was aiming towards the selection of parents with high general combining ability that could be included in seed orchards for the production of genetic material resistant to blister rust (Blada 1982, Blada and Popescu 2004).

\section{b. Neutral genetic variation}

Genetic variation has been recorded for the species by using mainly isozymes, ISSRs, RAPDs and SSR markers (Epperson and M.G. Chung 2001, Echt et al. 1996, Mehes et al. 2007). The high heterozygosity, as reported by Beaulieu and Simon (1994) and Echt et al. (1996), together with the phenotypic variation of Pinus strobus populations, indicated that significant gains in growth, timber quality, and stress-tolerance might potentially result from selection and breeding. High genetic variability was also revealed from studies of the existing gene diversity in natural stands of Pinus strobus before and after thinning by using isozymes and DNA markers. Echt (2000), by using DNA microsatellites, found that the genetic diversity of the 160 years old trees standing in stands of the species was the same with the genetic diversity of their natural regeneration, that occurred after shelterwood thinning, indicating the high levels of existing genetic variation. Also, in Newfoundland, Rajora et al. (1997) by using isozymes, found that genetic diversity of populations did not decline even after a century of population size decline, while they demonstrated that the Newfoundland populations were as genetically variable as those located in the core of the species distribution range (Ontario).

\section{Natural regeneration in Europe - genetic aspects}

Pinus strobus is naturally regenerating in Europe after its extensive introduction, while it has been proved to be highly invasive especially in Central Europe. At present it invades rapidly in sandstone areas, while it is becoming a main component of not only planted mixed forests but of other types of forests as well (Pyšek et al. 2002). Sparse occurrences have been recorded also on rocky sites. In Central Europe, many sandstone areas are protected for their unique environment and extensive regeneration of Pinus strobus may create problems for the conservation of the currently growing native species. Up to now many studies focused on the results of multiple introductions of a species, but the potential impacts of population admixture on the fitness of the introduced species have seldom being studied (Keller and Taylor 2010). Most of the studies stress the importance of genetic variation on the success of the introduction of a species, while genetic diversity can also be important for its long term stability. Admixture of introduced populations of different origins though, after their introduction and establishment, can result in the increase of their genetic diversity and could thus potentially increase their invasiveness (Chun et al. 2010, Keller and Taylor 2010). In this framework, Mandák et al. (2013) compared the large-scale genetic diversity of individuals from 30 sites in the native distribution range of Pinus strobus with that of individuals from 30 sites in the European distribution range, by using ten polymorphic microsatellite loci. They also studied the fine-scale genetic diversity patterns and changes over time within four highly invasive populations in the invaded part of the European range. From the above study it was demonstrated that the genetic diversity recorded within the range of the species in Central Europe is equal to the diversity recorded in the native range which is threefold larger. There was also no evidence of temporal increase in genetic diversity at the four highly invasive populations studied, which indicates that population admixture occurred prior to introduction and within the native range.

\section{References}

Beaulieu, J., Simon, J.P. (1994): Inheritance and linkage relationships of allozymes in Pinus strobus L. Silvae Genet $43: 253-261$.

Blada, I. (1982): Relative blister-rust resistance of native and introduced white pines in Romania. In: Heybroek, H. M. and others (Eds.): Resistance to disease and pests in forest trees. Workshop Gen. of Host-Parasite Inter. in Forestry, Wageningen, Holland. pp. 415-416.

Blada, I., Popescu, F. (2004): Genetic research and development of five-needle pines (Pinus subgenus strobus) in Europe: An Overview. In: Breeding and Genetic Resources of Five-Needle Pines: Growth, Adaptability and Pest Resistance. USDA For. Serv. RMRS-P-32. 276p.

Chun, Y. J., Fumanal, B., Laitung, B., Bretagnolle, F. (2010): Gene flow and population admixture as the primary post-invasion processes in common ragweed (Ambrosia artemisiifolia) populations in France. New Phytol 185: 1100-1107. 
Echt, C. S., May-Marquardt, P., Hseih, M., Zahorchak R. (1996): Characterization of microsatellite markers in eastern white pine. Genome, 39: 1102-1108.

Echt, C. S., Nelson C. D. (1997): Linkage mapping and genome length in eastern white pine (Pinus strobus L.). Theor. Appl. Genet. 94: 1031-1037.

Echt, S. C., Vendramin G. G., Nelson C. D., Marquard P. (2000): Microsatellite DNA as shared genetic markers among conifer species. Can. J. For. Res. 29: 365-371.

Echt, S. C. (2000): Use of microsatellite markers in management of conifer forest species. In: Strategies for Improvement of Forest Tree Species, Ed. G.C. Douglas. National Council for Research and Development, Dublin, Ireland, pp. 75-82.

Epperson, B. K., Myong Gi Chung. (2001): Spatial genetic structure of allozyme polymorphisms within populations of Pinus strobus (Pinaceae). Am. J. Bot. 88(6): 1006-1010.

Fowler, D. P. (1965): Effects of inbreeding in red pine, Pinus resinosa Ait. IV. Comparison with other northeastern Pinus species. Silvae Genet. 14: 76-81.

Garrett, P. W. (1972): Resistance of eastern white pine (Pinus strobus L.) provenances to the white pine weevil (Pissodes strobi Peck). Silvae Genet. 21: 119-121.

Genys, J. B. (1981): Preferences of Pissodes strobi in attacking different geographic strains of Pinus strobus. In: Proc. 17th IUFRO World Congress, 6-12 September 1981, Kyoto, Japan, pp. 191-194.

Heimburger, C. (1972): Relative blister rust resistance of native and introduced white pines in eastern North America. In Biology of Rust Resistance in Forest Trees. Proc. NATO-IUFRO advanced Study Institute, 17-24 August 1969, Moscow, ID. USDA Forest Serv. Misc. Pub. 1221, pp. 257-269.

Houston, D. B., Stairs, G. R. (1973): Genetic control of sulfur dioxide and ozone tolerance in eastern white pine. For. Sci. 19: 267-271.

Keller S. R., Taylor, D. R. (2010): Genomic admixture increases fitness during a biological invasion. J. Evol. Biol. 23: $1720-1731$.

Kriebel, H. B. (1978): Genetic selection for growth rate improvement in Pinus strobus. Genetika (Belgrade, Yugoslavia) 10(3): 269-276.

Kriebel, H. B. Leben, C. (1981): The impact of SO2 air pollution on the gene pool of eastern white pine. In Proc. XVII IUFRO World Cong., Kyoto, Japan, Div. 2, pp. 185-189.
Kriebel, H. B. (1982): Recommended genetic selections of some forest trees for Ohio. Ohio State Univ., Ohio Agr. Res. and Devel. Center, Res. Bul. 1148, 19 pp.

Kriebel, H. B., (2004): Genetics and Breeding of fiveneedle pines in the eastern United States. In: Breeding and Genetic Resources of Five-Needle Pines: Growth, Adaptability and Pest Resistance. USDA For. Serv. RMRS-P-32. 276p.

Little, E. L., Jr., (1971): Atlas of United States trees, volume 1, conifers and important hardwoods: U.S. Department of Agriculture Miscellaneous Publication 1146, 9 p., 200 maps.

Mader, D. L., (1985): Soil-site productivity for natural stands of white pine in the Northeast. In Symposium proceedings-Eastern white pine: Today and tomorrow. pp. 8-31. David T. Funk, comp. U.S.D.A. For. Serv., Gen. Tech. Rep. WO-51. Washington, D.C.

Mandák, B., Handicová, V., Mahelka, V., Wildová, R. (2013): European invasion of North American Pinus strobus at large and fine scales: High genetic diversity and fine-scale genetic clustering over time in the adventive range. PLOS ONE 8(7).

Mehes, M. S., Nkongolo, K. K., Michael, P. (2007): Genetic analysis of Pinus strobus and Pinus monticola populations from Canada using ISSR and RAPD markers: development of genome-specific SCAR markers. Pl. Syst. Evol. 267: 47-63.

Orlic, S. (1993): Research of Weymonth pine (P. strobus) provenances. Sumarski list, Zagreb. (9 - 10): 361-368.

Pyšek, P., Sádlo, J., Mandák, B., (2002): Catalogue of alien plants of the Czech Republic. Preslia 74: 97-186.

Radu, S. (1974): Cultura si valorificarea pinului strob. Editura Ceres, Bucuresti: 304 p.

Rajora, O. P., DeVerno, L., Moseler, L., Innes, D. J. (1997): Genetic diversity and population structure of disjunct Newfounland and central Ontario populations of eastern white pine (Pinus strobus). Can. J. For. Res. 76: 500-508.

Stephan, B. R. (1974): Zur geographisc Variation von Pinus strobus aufgrund erster Ergebnisse von Versuchsflächen in Niedersachsen. Silvae Genetica, 23 (6): 214220.

Stephan, B. R. (2004): Studies of Genetic Variation with Five-Needle Pines in Germany. In: Breeding and Genetic Resources of Five-Needle Pines: Growth, Adaptability and Pest Resistance. USDA For. Serv. RMRS-P-32. 276p. 
Thor, E., Gall, W. R. (1978): Variation in air pollution tolerance and growth rate among progenies of southern Appalachian white pine. In Proc. 1st Conf. Of the Metropolitan Tree Improvement Alliance (METRIA), pp. 80-86.

Wendel, G. W., (1980): Eastern white pine. In Forest cover types of the United States and Canada. pp. 25-26. F.H. Eyre, ed. Society of American Foresters, Washington, D.C.

Wendel, G. W., Smith, D. J. (1990): Pinus strobus L., Eastern White Pine, pp. 476-488. In R.M. Burns and B.H. Honkala (eds.), Silvics of North America, Vol. 1, Conifers, U.S.D.A. For. Serv. Agric. Handbk. 654, Washington, D.C.

Wright, J. W., Amiel, R. J., Cech, F. C., Kriebel, H. B., Jokela, J. J., Lemmien, W. A., Matheson, A. C., Merritt, C., Read, R. A., Roth, P., Thor, E., Thulin, I. J. (1979): Performance of eastern white pine from the southern Appalachians in eastern United States, New Zealand and Australia. In: Proc. 26th Northeastern For. Tree. Impr. Conf, University Park, PA, pp. 203-217. 


\title{
Pseudotsuga menziesii
}

\author{
Monika Konnert \\ Bayerisches Amt für forstliche Saat- und Pflanzenzucht \\ Forstamtsplatz 1, 83317 Teisendorf, Germany
}

\section{Natural distribution range}

Douglas-fir (Pseudotsuga menziesii (Mirb.) Franco) has the largest north-to-south distribution of any commercial conifer in North America. Within the native range two varieties of Douglas-fir are recognized: Pseudotsuga menziesii var. menziesii or viridis and Pseudotsuga menziesii var. glauca. In the zone of introgression (British Columbia) a third variety (Pseudotsuga menziesii var. caesia) was mentioned first by Schenk (1923) as an intermediate between the two clearly distinct races, i.e. menziesii and glauca. Pseudotsuga menziesii var. caesia was quickly accepted in Europe in spite of the fact that it was not clearly distinguishable by morphological characteristics (Flöhr 1958, Konnert 2009). The two varieties (menziesii or viridis and glauca) differ in size and crown form, cone morphological traits and needle colour, as well as in adaptive traits and growth rate.

The native range of both varieties resembles an inverted $\mathrm{V}$ with uneven sides, with the left arm stretching for over 2,200 kilometers and the right arm stretching for over 4,500 kilometers. The left arm of the V shaped distribution represents the native range of coastal Douglas-fir (Pseudotsuga menziesii var. menziesii), which extends from central British Columbia south along the Pacific Coast Ranges into central California. Within California, coastal Douglas-fir is predominately found on the western side of the Sierra Nevada and covers a good portion of Northwestern corner of the state. The native range of interior Douglas-fir (Pseudotsuga menziesii var. glauca), extends from central British Columbia south



Figure 1. Douglas-fir distribution range (source:https//en.wikipedia-org/wiki/Douglas-fir) 
along the Rocky Mountains and into the mountains of central Mexico (Hermann and Lavender 1999, Lavender and Hermann 2014). The coastal Douglas-fir ranges from sea level to about $1,500 \mathrm{~m}$ (locally even more). The inland variety grows at altitudes from about $500 \mathrm{~m}$ to $3,200 \mathrm{~m}$ in Mexico. The principal limiting factors for distribution are temperature in the north and moisture in the south of the range.

\section{Genetic variability}

\section{a. Adaptive genetic variation}

\section{Results of breeding efforts within the species natural range}

The natural distribution of Douglas-fir is one of the widest among tree species, and covers an extensive geographical and climatic gradient. This has led to the development of genetically different populations, which are well adapted to their ecological niches. In this context Douglas-fir is considered to be an adaptive specialist. Thus, even populations separated only by 100 to $200 \mathrm{~m}$ in elevation can differ in adaptive traits (Rehfeldt 1979).

Patterns of genetic variation in adaptive traits have been studied in short-term common-garden studies in nurseries, greenhouses or growth chambers (St Clair et al 2005, St. Clair 2006, St. Clair and Howe 2007, Hawkins and Stoehr 2009) and in long-term provenance and progeny tests (Breidenstein et al 1990, Kleinschmit et al. 1991, Eilmann et al. 2013). Whereas the first ones give the possibility to evaluate rapidly many traits, they give no information on the behaviour within a longer time period and during extreme climatic events or pest attacks. Longterm provenance trials provide all the above information but are costly in resources and time (Johnson et al. 2004). This together with the possibility to measure a large number of mostly adaptive traits on a high number of genotypes in one to three years is why short-term studies are today preferred for the examination of adaptive traits of Douglas-fir along the landscape. Mainly all studies have demonstrated varietal differences (Rehfeldt 1977, Silen 1978, Sorensen 1979) and generally clinal variation patterns in tree growth, phenology and cold hardiness. Compared to coastal populations the interior populations set bud earlier and are more tolerant to fall frost, winter cold and droughts. Within both Douglas-fir varieties (coastal and interior) west to east clines in adaptive traits are substantial (Kung and Wright 1972, Rehfeldt 1978, Campbell and Sorensen 1978, Sorensen 1983). North to south clines are less pronounced and seem to be stronger in the northern part of the interior Douglas-fir distribution range (Hernandez et al. 1993, Howe et al. 2006).

The timing of bud burst and bud set has been shown to be related to elevation, latitude, longitude and distance from the ocean. Populations from higher elevations, more northern latitudes and greater distance from the ocean, are mainly populations from colder locations that typically set bud earlier and are more tolerant to fall frosts and winter cold. At the other side the populations flush slightly earlier in spring and are, therefore, more susceptible to late frost events (Aitken et al. 1996, Balduman et al. 1999, St. Clair et al. 2005). Within both varieties drought hardiness seems to increase from north to south but also from west to east (White 1987). Interior Douglas-fir seems to be more resistant to winter drought than coastal Douglasfir. Among the relatively winter drought sensitive coastal provenances there was an increase in winter drought resistance with increasing elevation (Larsen 1981).

Long-term provenance tests in the natural range (White and Ching 1985, Jaquish 1990, Adams and Campbell 1981, Silen 1978) illustrated that coastal Douglas-fir populations have a higher growth rate than the interior ones. Populations from the transition zone in British Columbia and the northern Rocky mountains (the so called "grey" Douglas-fir - var. caesia) are intermediate in growth. Coastal provenances are more tolerant to both Rhabdocline needle cast and Swiss needle cast disease. Within the interior range, northern populations (British Columbia, Washington, Oregon, Idaho, Montana) seem to be more tolerant to Rhabdocline than populations from the southern part (Colorado, Utah, Arizona, New Mexico) (Bastien et al. 2013).

In the Pacific Northwest extensive breeding programmes for Douglas-fir are carried out with more than 4 million progenies from nearly 34,000 selected trees growing in more than 1,000 test sites (Howe and St. Clair 2007). Breeding began in the 1950's when some government agencies, forest companies and forestry associations started to select plus trees from Costal Douglas-fir and established clonal seed orchards. Step by step the different breeding programs were brought together. Today most Douglasfir improvement is carried out by four organizations: the Northwest Tree Improvement Cooperative (NWTIC), the Inland Empire Tree Improvement Cooperative (IETIC), the British Columbia Ministry of Forests (BCMoF) and Weyerhaeuser Company (Howe et al. 2006). The main goals of Douglas-fir breeding programs are to improve the economic value of tree crops, to maintain adaptability and to increase disease resistance. In consequence important traits of interest are stem volume and quality, wood quality, spring and fall frost hardiness, drought hardiness, Swiss needle cast and Rhabdocline needle cast resistance, Armillaria and Phellinus root resistance. 
The four above mentioned organizations have alternative approaches for selection, breeding zones, testing, seed orchards and deployment of improved material.

The NWTIC is an umbrella organization housed since 2004 at Oregon State University that coordinates a decentralized system of independent cooperatives. The costs of breeding and testing are shared among the members of these cooperatives. Seed orchards are managed by individual organizations that are mostly independent from NWTIC. The NWTIC breeding program of Douglas-fir started in the first generation with a low-intensity selection of first generation parents, use of many small breeding zones and very large breeding populations which consisted of parents selected from natural stands within the breeding zone (Silen and Wheat 1979). Meanwhile more than 26,000 parent trees have been evaluated (Lipow et al. 2003) and the large number of breeding zones was reduced to eight second-generation zones. About 2,000 parents are selected for advanced-generation breeding (Howe et al. 2006).

The IETIC conducts improvement of Douglas-fir for planting in eastern Washington, northern Idaho and western Montana. Since 1974 in most of the 13 breeding zones 200-300 trees were selected. More than 2,500 first generation parents have been field tested until now. Four Douglas-fir seed orchards were established.

In British Columbia first-generation selection and testing began around 1960 for coastal Douglas-fir and 1980 for interior Douglas-fir. Since 1998 the Forest Genetics Council (FGC) among other duties coordinates the operational tree improvement programs and the management of seed orchards. Within the FGC the British Columbia Ministry of Forests is responsible for Douglas-fir breeding. In the first years the program includes intensive plus-tree selection, developing inbred lines for subsequent outcrossing, creating interracial hybrids and testing provenances within coastal British Columbia (Orr-Ewing 1972, Heaman 1977). Later on a pedigreed breeding population was created by using structured mating designs. In the coastal program about 660 parents were tested in 130 field test. Field tests showed for example that the average gain of the MidGain families over the control was $12 \%$, while the TopCrosses outperformed the controls by an average of $17 \%$ (Stoehr et al. 2008). Currently, the breeding population for Coastal Douglas-fir contains 360 genotypes and is subdivided into 30 sublines, each of which is including 10 to 15 parents, for future testing and breeding. The parents resulting from the tree selection and breeding program are planted in seed orchards. Each orchard is comprised of clones (or occasionally seedlings) of up to 100 or more parents. The trees included in one orchard are adapted to a particular set of biogeoclimatic conditions, a Seed
Planning Zone (SPZ). SPZs are groupings by seed zone and elevation-bands and form the basis for tree breeding and seed production planning. For Coastal Douglas-fir there are three, for interior Douglas-fir seven SPZs.

Weyerhaeuser Company runs a large breeding program since 1963. It started with an intensive plus-tree selection in natural stands aged 25 to 80 years. Altogether 3,500 trees were selected in six breeding zones in western Washington and western Oregon. The primary objective of the firstgeneration program was growth and stem quality (Howe et al. 2006, Stonecypher et al. 1996, Woods 1993). The second-generation populations are nearly completed, the third generation of improvement is underway. As a result of intensive field tests the number of breeding zones were reduced to one in Washington and two in Oregon. The long term goal is to produce elite material via windpollinated seed orchards and somatic embryogenesis.

Actually in the Pacific Northwest nearly only seed from seed orchards is used for afforestation. This seed performs better, but there is no interest from the producers side to sell the seed to Europe (Schüler and Weißenbacher 2016).

\section{Results of breeding efforts in Europe}

Provenance trials established in Europe confirmed the results obtained from common-garden experiments established in the natural distribution range, i.e. that interior populations (especially in British Columbia) are the more resistant to early and winter frosts, but susceptible to late frosts in spring, whereas the opposite is true for the coastal populations with late flushing. Latitude, distance to the Pacific Ocean and elevation explain most of the between-population variation in frost resistance (Bastien et al. 2013).

In the European provenance trials the growth superiority of the coastal Douglas-fir provenances from lower elevation from the coastal and Cascade range in Washington state was demonstrated (e.g. Breidenstein et al. 1990, Kleinschmit et al. 1991, Eilmann et al. 2013). Populations from the Darrington and Humtulips region are the best growing in a broad range of environments. Some coastal seed sources from Oregon performed well in southern European sites. In Northern Europe (e.g. Sweden) or in high elevation sites $(>1,300 \mathrm{~m})$ some sources from the transition zone (var. caesia) had better growth than coastal provenances (Bastien et al. 2013).

The patterns described above need to be considered when seed is transferred from the natural range to Europe. With increasing interest in climate change, researchers are revisiting questions of use of appropriate provenances and are using data from provenance trials to explore relation between provenance performance and climate 
(e.g. Rehfeldt et al. 1999, Matyas 1994, Chakraborty et al. 2015) and also to predict adaptive response of populations under future climatic conditions (Wang et al. 2010). It was shown (Chakraborty et al. 2015) that the temperature experienced in the place of origin is decisive for the performance of the introduced genetic material, while the annual precipitation or the precipitation pattern had no effect.

\section{b. Neutral genetic variation}

The first range-wide investigation of the genetic structure of Douglas-fir was done by Li and Adams (1989) based on isozymes. With these markers the two varieties - coastal and interior could by separated clearly on the basis of the frequencies of specific marker alleles (e.g. 6-PGDH-A3 and A6, PGM-A4 and A6). The findings of Li and Adams (1989) support also separation of the interior variety into a northern and a southern subgroup, with a transition zone located at Latitude $44^{\circ} \mathrm{N}$. This was confirmed by an isozyme study of Klumpp (1999) that was conducted on commercial seed from 27 seed sources within the natural range and buds from 11 populations in Germany. Based on so called "ecotype reference vectors", which are a combination of frequencies of specific alleles (namely 6-PGDH-A4 resp. A6, GOT-B3, IDH-A5, LAP-A2 and $\mathrm{SKDH}-\mathrm{B} 1)$ he distinguished 10 ecotypes within the natural range of Douglas-fir (four between the interior, six between the coastal variety) and tried to trace back the origin of German stands.

Employing molecular markers from both the paternally inherited chloroplast genome and the maternally inherited mitochondrial genomes Wei et al (2011) delineated six geographical subdivisions: Coastal-north, Coastalsouth, Rockies-north, Rockies-transition, Rockies-south and Mexico. The Mexican lineage, was characterized by the lowest genetic diversity but highest population differentiation and can clearly be differentiated by means of these methods. A differentiation between coastal and interior subdivisions is also possible. The two coastal subdivisions and the Rockies-south are characterized by unique mitotypes resp. clorotypes. The hybrid zone between varieties (var. caesia) shows both mitotypes and chlorotypes (Gugger et al. 2010). Hence an unequivocal allocation of seed and plants, or of European stands, to one of the two varieties - coastal or interior -is not possible based on mitotypes or chlorotypes. However, the method can be applied as a complement to investigations with isozymes and nuclear microsatellites.

The development and use of polymorphic nuclear microsatellites (Slavov et al. 2004, Krutovski et al. 2009) offer new insights into the genetic structure and gene flow at the intra-varietal and inter-varietal level (van Loo et al.
2015) and possibilities for proof of origin of Douglas-fir stands from outside the natural range. Following Fussi et al (2013) the nSSR-loci PmOSU_3B2 and PmOSU_4A7 were the most efficient in distinguishing the coastal and interior varieties. By the combination of isozymes and nSSRs a more precise allocation of populations in Germany to seed zones seems to be possible.

Using 13 nSSR loci Van Loo et al. (2015) identified, besides a clear distinction between coastal and interior varieties, the intervarietal contact/hybrid zones in interior $\mathrm{BC}$ (similar to the region which is attributed to the var. caesia) but also along the Eastern Cascades in Washington and Oregon. This has to be considered when seed is imported.

\section{References}

Adams, W. T., Campbell, R. K. (1981): Genetic adaption and seed source specificity. In: S.D. Hobbs, and O.T. Helgerson (eds.): Reforestation of skeletal soils, Proc. Reforestation Workshop, Medford, OR, 17-19 Nov. 1981, Forest Research Laboratory, Oregon State Univ., Corvallis, pp. 78-85.

Aitken, S. N., Adams, W. T., Schermann, N., Fuchigami, L. H. (1996): Family variation for fall cold hardiness in two Washington populations of coastal Douglas-fir (Pseudotsuga menziesii var. menziesii [Mirb.] Franco). For. Ecol. Management 80: 187-195.

Balduman, L. M., Aitken, S. N., Harmon, M., Adams, W. T. (1999): Genetic variation in cold hardiness of Douglas-fir in relation to parent tree environment. Can. J. For. Res. 29: 62-72.

Bastien, J. Ch., Sanchez, L., Michaud, D. (2013): Douglas-Fir (Pseudotsuga menziesii (Mirb.) Franco. In: L.E. Paques (ed.): Forest Tree Breeding in Europe: Current State-of-the-Art and Perspectives. Managing Forest Ecosystems 25, DOI 10.1007/978-94-007-61469_7. Springer Science+Business Media Dordrecht, pp 325 -359 .

Breidenstein, J., Bastien, J. C., Roman-Amat, B. (1990): Douglas-fir range wide variation from the IUFRO data base. Proceedings IUFRO working party meeting S 2.02.05 "Douglas-fir improvement", Olympia, Washington, Aug. 20-25, 1990. 
Campbell, R. K., Sorensen, F. C. (1978): Effect of test environment on expression of clines and on delineation of seed zones in Douglas-fir. Theor. Appl. Genet. 51: 223-246.

Chakraborty, D., Wang, T., Andre, K., et al. (2015): Selecting Populations for Non-Analogous Climate Conditions Using Universal Response Functions: The Case of Douglas-Fir in Central Europe. PLOS ONE 10:e0136357. doi: 10.1371/journal.pone.0136357.

Eilmann, B., de Vries, S. M. G., den Ouden, J., Mohren, G. M. J., Sauren, P., Sass-Klaassen, U. (2013): Difference in drought tolerance and productivity of coastal Douglasfir (Pseudotsuga menziesii (Mirb.)) provenances. Forest Ecology and Management 302: 133-143.

Flöhr, W. (1958): Kennzeichnung, Varietäten und Verbreitung der Douglasie. In: Göhre, K., Wagenknecht, E. (Hrsg.): Die Douglasie und ihr Holz. Berlin, Akademieverlag, 4-10.

Fussi, B., Dounavi, A., Konnert, M. (2013): Identification of varieties and gene flow in Douglas-fir exemplified in artificially established stands in Germany. Annals of forest research 56(2): 249-268.

Gugger, P. F., Sugita, S., Cavender-Bares, J. (2010): Phylogeography of Douglas-fir based on mitochondrial and chloroplast DNA sequences: testing hypotheses from the fossil record. Molecular Ecology 19: 1877-1897.

Hawkins, B. J., Stoehr, M. (2009): Growth, phenology, and cold hardiness of 32 Douglas-fir full-sib families, Canadian Journal of Forest Research 39 (10): 1821-1834.

Heaman, J. C. (1977): Choosing strategies for a breeding program in Douglas-fir (Pseudotsuga menziesii) for coastal British Columbia - A case study. In: A.G. Brown, and C.M. Palmberg (eds.): Proc. FAO/IUFRO Third World Consultation Forest Tree Breeding, Vol. 2, Canberra, Autralia, 21-26 March 1977, CSIRO, Canberra, Australia. pp. 1205-1214.

Hermann, R. K., Lavender, D. P. (1999): Douglas-fir planted forests. New Forests 17 (1-3): 53-70.

Hernandez, G. T., Alonso, G. V., Arribas, G. P., Jenkinson, J. L. (1993): Screening Douglas-fir for rapid growth in common-garden test in Spain. USDA For. Serv. Gen. Tech. Rep. PSW-GTR-146, Albany, Ca.

Howe, G. T., Jayawickrama, K., Cherry, M. (2006): Breeding Douglas-fir. In: Janick, J. (Ed.): Plant Breeding Reviews, Volume 27, John Wiley \& Sons, Inc., pp. 245 -353 .
Howe, G. T., St.Clair, B. (2007): Douglas-fir Breeding: Past Successes and Future Challenges. In: Tree Improvement and Genetics - Southern Forest Tree Improvement Conference 2007.

Jaquish, B.C. (1990): Geographic variation in ten-year height growth of interior Douglas-fir in British Columbia. In Proc. Joint Meeting Western Forest Genetics Assoc. and IUFRO Working Parties S2.02-05, 06, 12, and 14 Douglas-fir, Contorta pine, Sitka spruce and Abies breeding and genetic resources, Olympia, WA, 20-24 Aug. 1990, Weyerhaeuser Co., Federal Way, WA. pp. $2.144-2.155$.

Johnson, G. R., Sorensen, F. C., St.Clair, J. B., Cronn, R. C. (2004): Pacific Northwest forest tree seed zones. A template for native plants?. Native Plants/Fall. 131-140.

Kleinschmit, J., Svolba, J., Weisgerber, H., Rau, H. M., Dimpflmeier, R., Ruetz, W. F., Franke, A. (1991): Ergebnisse des IUFRO-Douglasien-Herkunftsversuches in West-Deutschland im Alter 20. Forst und Holz 9: 238 -242 .

Klumpp, R. (1999): Untersuchungen zur Genökologie der Douglasie (Pseudotsuga menziesii (Mirb.) Franco). Dissertation der Fakultät für Forstwissenschaften u. Waldökologie der Universität Göttingen. 290 S.

Konnert, M. (2009): Genetische Aspekte und Herkunftsfragen bei der Douglasie. Eberswalder Forstliche Schriftenreihe 43: 28-32.

Krutovsky, K. V., St. Clair, J. B., Saich, R., Hipkins, V. D., Neale, D. B. (2009): Estimation of population structure in coastal Douglas-fir [Pseudotsuga menziesii (Mirb.) Franco var. menziesii] using allozyme and microsatellite markers. Tree Genet. Genomes 5: 641-658.

Kung, F. H., Wright, J. W. (1972): Parallel and divergent evolution in Rocky Mountain trees. Silvae Genet. 21:7785.

Larsen, J. B. (1981): Geographic variation in winter drought resistance of Douglas-fir (Pseudotsuga menziesii Mirb. Franco). Silvae Genet. 30: 109-114.

Lavender, D. P., Hermann R. K. (2014): Douglas-Fir: The Genus Pseudotsuga, OSU College of Forestry.

Li, P., Adams, W. T. (1989): Range-wide patterns of allozyme variation in Douglas-fir (Pseudotsuga menziesii). Can J For Res 19: 149-161.

Lipow, S. R., Johnson, G. R., St. Clair, J. B., Jayawickrama, K. J. (2003): The role of tree improvement programs for ex situ gene conservation of coastal Douglasfir in the Pacific Northwest. For. Gen. 10: 111-120. 
Matyas, C. (1994) Modeling climate change effects with provenance test data. Tree Physiology 14: 797-804.

Orr-Ewing, A. L., Fraser, A. R., Karlsson, I. (1972): Interracial crosses with Douglas-fir: Early field results. B.C. For. Serv. Res. Note 55.

Rehfeldt, G. E. (1977): Growth and Cold Hardiness of Intervarietal Hybrids of Douglas-fir. Theor. Appl. Genet. 50: 3-15.

Rehfeldt, G. E. (1978): Genetic differentiation of Douglas-fir populations from the northern Rocky Mountains. Ecology 59: 1264-1270.

Rehfeldt, E. G. (1979): Ecological adaptations in Douglasfir (Pseudotsuga menziesii var. glauca) populations. I. Idaho and northeast Washington. Heredity 43: 383-397.

Rehfeldt, G. E., Ying, C. C., Spittlehouse, D. L., Hamilton, D. A. Jr. (1999): Genetic responses to climate for Pinus contorta in British Columbia: niche breadth, climate change, and reforestation. Ecological Monographs 69: 375-407.

Schenk, C. A. (1939). Fremdländische Wald- und Parkbäume. Vol. 2. Die Nadelhölzer. Paul Parey, Berlin.

Schüler, S., Weißenbacher, L. (2016): Unterwegs in der Heimat der Douglasie. Forstzeitung, Wien, 127(2): 34-35 and (3): 36-37.

Silen, R. R. (1978): Genetics of Douglas-fir. USDA For. Serv. Res. Pap. WO-35.

Silen, R. R., Wheat, J. G. (1979): Progressive tree improvement program in Douglas-fir. J. For. 77: 78-83.

Slavov, G. T., Howe, G. T., Yakovlev, I., Edwards, K. J., Krutovsky, K. V., Tuskan, G. A., Carlson, J. E., Strauss, S. H., Adams, W. T. (2004): Highly variable SSR markers in Douglas-fir: Mendelian inheritance and map locations. Theoretical Applied Genetics 108: 873-880.

Sorensen, F. C. (1979): Provenance variation in Pseudotsuga menziesii seedlings from the var. menziesii var. glauca transition zone in Oregon. Silvae Genet. 28: 96-103.

Sorensen, F. C. (1983): Geographic variation in seedling Douglas-fir (Pseudotsuga menziesii) from the western Siskiyou Mountains of Oregon. Ecology 64: 696-702.

St.Clair, J. B., Mandel, N. L., Vance-Borland, K. W. (2005): Genecology of Douglas-fir in western Oregon and Washington. Annals of Botany 96: 199-1214.
St.Clair, J. B. (2006): Genetic variation in fall cold hardiness in coastal Douglas-fir in western Oregon and Washington. Canadian Journal of Botany 84: 1110-1121.

St.Clair, J. B., Howe, G. T. (2007): Genetic maladaptation of coastal Douglas-fir seedlings to future climates. Global Change Biology 13: 1441-1454, doi: 10.1111/j.13652486.2007.01385.x.

Stoehr, M., Yanchuk, A., Xie, C.-.Y, Sanchez, L. (2008): Gain and diversity in advanced generation coastal Douglas-fir selections for seed production populations. Tree Genet. Genomes 4(2): 193-200.

Stonecypher, R. W., Piesch, R. F., Helland, G. G., Chapman, J. G., Reno, H. J. (1996): Results from genetic tests of selected parents of Douglas-fir (Pseudotsuga menziesii) in an applied tree improvement program. For. Sci. 42, Monograph 32: 1-35.

van Loo, M., Hintsteiner, W., Pötzelsberger, E., Schüler, S., Hasenauer, H. (2015): Intervarietal and intravarietal genetic structure in Douglas-fir: nuclear SSR bring novel insights into past population demographic processes, phylogeography, and intervarietal hybridization. Ecology and Evolution 2015: 5(9): 1802-1817.

Wang, T., O'Neill, G. A., Aitken, S. N. (2010): Integrating environmental and genetic effects to predict responses of tree populations to climate. Ecological Applications 20: 153-163.

Wei, X.-X., Beaulieu, J., Damase, P. K., VargasHernández, J., López-Upton, J., Jaquish, B., Bousquet, J. (2011): Range-wide chloroplast and mitochondrial DNA imprints reveal multiple lineages and complex biogeographic history for Douglas-fir. Tree Genet. Genomes 7: 1025-1040.

White, T. L. (1987): Drought tolerance of southwestern Oregon Douglas-fir. For. Sci. 33: 283-293.

White, T. L., Ching, K. K. (1985): Provenance study of Douglas-fir in the Pacific Northwest region. IV. Field performance at age 25 years. Silvae Genet. 34: 84-90.

Woods, J. H. (1993): Breeding programs and strategies for Douglas-fir in North Amercia. In: Y.S. Park and G.W. Adams (eds.): Breeding strategies of important tree species in Canada. Natural Resources Canada, Fredericton, N.B. Inform. Rep. M-X-186E, pp. 1-11. 


\section{Quercus rubra}

\section{Marjana Westergren}

Slovenian Forestry Institute, Vecna pot 2, 1000 Ljubljana, Slovenia

\section{Distribution range}

\section{a. Natural distribution range}

Northern red oak (Quercus rubra) is widely distributed throughout much of the eastern United States and southeastern Canada between $32^{\circ}$ and $47^{\circ} \mathrm{N}$ latitude and $60^{\circ}$ and $96^{\circ} \mathrm{W}$ longitude. It grows from Quebec, Ontario, Nova Scotia, and New Brunswick southward to southwestern Georgia and Alabama. Northern red oak extends westward through Minnesota and Iowa, south through eastern Nebraska and Kansas to eastern Oklahoma. It occurs locally in eastern and southwestern Louisiana and western Mississippi (disjunct populations).

Often, although not consistently, two varieties of Q. rubra are reported. Currently, USDA NRCS Plant guide (http:// plants.usda.gov/plantguide/pdf/cs_quru.pdf) uses terms Q. rubra var. rubra and Q. rubra var. ambigua (A. Gray) Fernald for these varieties.

The variety Q. rubra var. rubra grows in Georgia and Alabama, northward through Kentucky, Tennessee, and West Virginia to New England. The variety Q. rubra var. ambigua occurs farther north than variety rubra does. In the major part of the distribution range the two varieties overlap.

Q. rubra is a member of the red oak subgroup (subg. Erythrobalanus $=$ sect. Lobatae) and hybridizes with related species, including $Q$. coccinea, $Q$. ellipsoidalis, Q. imbricata, $Q$. ilicifolia, $Q$. marilandica, $Q$. palustris, Q. phellos, Q. shumardii, and Q. velutina.

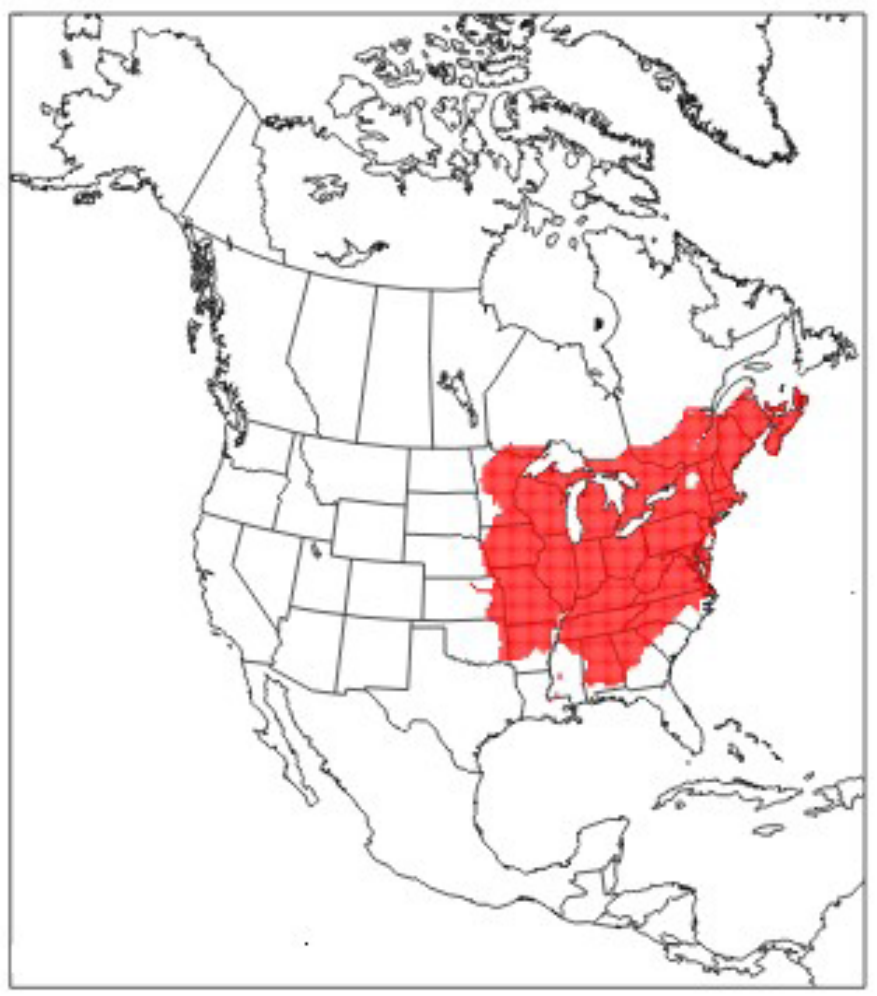

Figure 1. Distribution map of Quercus rubra. 


\section{Genetic Variation}

\section{a. Adaptive genetic variation}

\section{Results of breeding efforts within the species natural range}

Provenance trials have been established within the native range of the species (Kriebel et al. 1976, Kriebel 1993, Schlarbaum and Bagley 1981). From the results obtained it was revealed that traits varying geographically include height and diameter growth rate (at 24 years of age). Height growth means were almost always highest in trees from provenances between latitudes $43^{\circ}$ and $46^{\circ} \mathrm{N}$ in an east-west zone extending from the Mississippi River to western Maine. Trees from outside of this zone were, on the average, slower-growing. It was also shown that Q. rubra varies geographically in drought resistance. Trees from provenances in low rainfall regions west of the Mississippi River (lowa, Kansas, Missouri), near the range limits, were more drought-resistant than those of other origins. Cold hardiness was strongly related to estimated mean annual minimum temperature of the origin and to latitude of the origin. Date of bud-break or leaf flushing of northern red oak depends upon seed source; in the north central region of the USA, flushing begins in trees of northwestern origin (Minnesota, Wisconsin, upper Michigan), then proceeds 'eastward' through trees of northern origin to trees of northeastern origin, and also 'southward' to trees of central and southern provenance, ending in trees of midlatitude origins from southern Michigan to Pennsylvania. This trend is not significantly correlated with latitude and it is only weakly correlated with longitude. In eastern Tennessee, the pattern of flushing is very different: the general trend begins in trees of southern origins and ends in trees of northern origins. The time of leaf senescence proved to be strongly correlated with the latitude of the seed source, progressing clinally from north to south.

Literature about breeding programs in the natural range is scarce. Oak improvement in the US and Canada is performed mainly by public agencies and institutions. In 1990, 19 Q. rubra improvement programs, mainly oriented towards timber and veneer production, existed (Steiner 1993).

\section{Results of breeding efforts in Europe}

Twenty eight provenance trials currently exist in France. According to Daubree and Kremer (1993) who summarized the results from provenance trials in France, continuous latitudinal variation was revealed in flushing and leaf coloration in natural populations (seed originated from the natural range). However, the pattern of flushing in French trials differed from the one observed in the trials established in the natural range, while the pattern of leaf coloration was similar in trials both in the natural range and in France. No latitudinal or longitudinal trend of variation in flushing nor in leaf coloration for introduced populations (seed originating from French stands) was reported. Also, a smaller range of variation for flushing and leaf coloration was observed in introduced populations (seed originating from French stands).

Liesebach and Schneck (2011) reported that 4 provenance trials were established in 1991 in Germany, while of them 3 remained after the first year. 15 north-American and 12 European provenances were tested in this trials (European seed sources were from Germany, but also one was from the Netherlands and one from Poland). At age 10, significant differences were found in height growth between the sites. Provenances differed in growth and quality. Most of the provenances from Europe were better than those originating from N. America. Flushing and autumn leaf coloration were assessed over several years and were correlated.

Based on those results the following recommendation for the cultivation can be made:

For establishment of Q. rubra stands seeds should only be harvested from well growing and well-formed populations in Germany. Further yield increase cannot be expected by importing seeds from the natural distribution area (Liesebach and Schneck 2011).

Establishment of provenance trials in Belgium, Bulgaria, Turkey and the United Kingdom has also been reported.

\section{b. Neutral genetic variation}

Using isoenzymes, frequency profiles of rare alleles on loci PGI, PGM, MDH and SKDH provide some means to differentiate some of the populations within the natural range, in particular the ones from Quebec from the rest of the range (Daubree and Kremer 1993). In a study of Sork et al. (1993) 10 populations from the midwestern US showed moderate levels of genetic differentiation among populations at 11 isozyme loci. Genetic differentiation among adjacent subpopulations was extremely low. At the other side Houston (1983) reported about the differentiation of 11 seed sources (material from a provenance trial) based on the presence or absence of one or more peroxidase isoenzyme bands, or by large frequency differences.

Chloroplast markers show only limited differentiation (Magni et al. 2005). However, using chloroplast PCRRFLP, there was a clear regional trend of population differentiation along a latitudinal gradient (Magni et al 2005). On a smaller scale, Romero-Severson et al. (2003) found most of genetic variation resided among rather 
than within populations, but too few populations in only a limited part of the natural range were studied. While a lot of nuclear markers (genomic SSR, EST-SSR) have been developed recently (Aldrich et al. 2002, Aldrich et al. 2003, Sullivan et al. 2013) they have not yet been tested in range wide studies.

\section{Natural regeneration in Europe}

In Europe, Q. rubra typically grows with shade-tolerant species. Q. rubra regenerates naturally and successfully in Europe (e.g. Major et al. 2013, Kuehne et al. 2014); seedling density under seed trees can be very high (Major et al. 2013). Lack of seedlings beyond $15 \mathrm{~m}$ from a seed tree suggested limited seed dispersal (Major et al. 2013). A case study from the natural range reports seed dispersal distance estimated from seed trap data to $9 \mathrm{~m}$ (Clark et al. 1998) while another study, based on molecular data and simulations reports seed dispersal to be $125 \mathrm{~m}$ (Moran and Clark 2011). Major et al. (2013) also reported anecdotal observations by local foresters that mast years in the stands near Freiburg in Germany were more frequent than those in the native range where Q. rubra stands generally produce seed crops every $2-5$ years.

According to Daubree and Kremer (1993), seed collected from introduced stands in Europe was of better quality than seed from the natural range.

Periodic thinning operations seem to promote the dominance of $Q$. rubra in the regeneration layer of European mixed hardwood forests, according to a case study in Germany (Major et al. 2013).

\section{References}

Aldrich, P. R., Jagtap, M., Michler, C. H., RomeroSeverson, J. (2003): Amplification of North American red oak microsatellite markers in European white oaks and Chinese chestnut. Silvae Genet 52: 176-179.

Aldrich, P. R., Michler, C. H., Sun, W.L., RomeroSeverson, J. (2002): Microsatellite markers for northern red oak (Fagaceae: Quercus rubra). Mol Ecol Notes 2: 472474 .

Clark, J. S., Macklin, E., Wood, L. (1998): Stages and spatial scales of recruitment limitation in southern Appalachian forests. Ecological Monographs, 68: 213-235.

Daubree, J. B., Kremer, A. (1993): Genetic and phenological differentiation between introduced and natural populations of Quercus rubra L. Annals of Forest Science 50: 271-280.
Houston, D. B. (1983): Stand and seed source variation in peroxidase isozymes of Quercus rubra L. Silvae Genetica 32: 59-63.

Kriebel, H. B., Bagley, W. T., Deneke, F. J., Funsch, R. W., Roth, P., Jokela, J. J., Merritt, C., Wright, J. W., Williams, R. D. (1976): Geographic Variation in Quercus rubra in North Central United States Plantations. Silvae Genetica 25: 118-126.

Kuehne, C., Nosko, P., Horwath, T., Bauhus, J. (2014): A comparative study of physiological and morphological seedling traits associated with shade tolerance in introduced red oak (Quercus rubra) and native hardwood tree species in southwestern Germany. Tree Physiol first published online February 14, 2014 doi:10.1093/treephys/tpt124.

Liesebach, M., Schneck, V. (2011): Entwicklung von amerikanischen und europäischen Herkünften der Roteiche in Deutschland. Forstarchiv 82: 125-133.

Magni Diaz, C. R. (2004): Reconstitution de l'introduction de Quercus rubra L. en Europe et conséquences génétiques dans les populations allochtones. $\mathrm{PhD}$ thesis, Ecole Nationale du Génie Rural, des Eaux et des Forêts de Paris.

Magni, C. R., Ducousso, A., Caron, H., Petit, R. J., Kremer A. (2005): Chloroplast DNA variation of Quercus rubra L. in North America and comparison with other Fagaceae. Molecular Ecol. 14: 513-524.

Major, K. C., Nosko, P., Kuehne, C., Campbell, D., Bauhus, J. (2013): Regeneration dynamics of nonnative northern red oak (Quercus rubra L.) populations as influenced by environmental factors: A case study in managed hardwood forests of southwestern Germany. Forest Ecology and Management 291: 144-153.

Moran, E. V., Clark, J.S. (2011): Estimating seed and pollen movement in a monoecious plant: a hierarchical Bayesian approach integrating genetic and ecological data. Molecular Ecology 20: 1248-1262.

Romero-Severson, J., Aldrich, P., Feng, Y., Sun, W.L., Michler, A. (2003): Chloroplast DNA variation of northern red oak (Quercus rubra L.) in Indiana. New Forests 26: 43-49.

Steiner, K. C. (1993): Genetic improvement of oaks in North America. Annales des sciences forestieres 50: 359-367.

Schlarbaum, S. E., Bagley, W.T. (1981): Intraspecific genetic variation of Quercus rubra $\mathrm{L}$, northern red oak. Silvae Genetetica 30: 50-56.

Sork, V. L., Huang, S., Wiener, E. (1993): Macrogeographic and fine-scale in a North American oak species, Quercus rubra L. Ann Sci For (suppl 1), 261-270. 
Steiner, K. C. (1993): Genetic improvement of oaks in North America. Ann. For. Sci. 50(1): 359-367.

Sullivan, A., Lind, J., McCleary, T. S., Romero-Severson, J., Gailing, O. (2013): Development and characterization of genomic and gene-based microsatellite markers in North American red oak species. Plant Molecular Biology Reporter 31: 231-239. 


\title{
Robinia pseudoacacia
}

\author{
Marcela van Loo ${ }^{1}$, Renata Milcevicova ${ }^{2}$, Marjana Westergren ${ }^{3}$
}

\begin{abstract}
${ }^{1}$ University of Vienna, Department of Botany and Biodiversity Research, Rennweg 14, 1030 Vienna, Austria ${ }^{2}$ University of Natural Resources and Life Sciences (BOKU), Department of Forest \& Soil Sciences, Institute of Silviculture, Peter Jordanstr. 82, 1190 Vienna, Austria

${ }^{3}$ Slovenian Forestry Institute, Vecna pot 2, 1000 Ljubljana, Slovenia
\end{abstract}

\section{Distribution range}

\section{a. Natural distribution range}

The distribution of Robinia pseudoacacia L. (black locust, false acacia, robinia) in its native range, in the eastern USA, is disjunct. Two distinct areas and several outlying populations are commonly characterised within this native range. The larger area coincides with the Appalachian Mountains; the smaller one is located in the states Arkansas, Missouri and Oklahoma (Little 1976). The precise extent of the native range, however, is not accurately known as black locust has been widely planted and become naturalized throughout North America. Today, black locust is spread in every state of the USA and also in British Columbia, Québec, Newfoundland and Labrador in Canada. In natural populations, clonal structures are present due to the black locust's ability to reproduce also asexually by root suckers (Chang et al. 1998).

The genus Robinia is represented by 4-10 species (depending on the cited Flora), which are native to North America and northern Mexico. Naturally distributed $R$. pseudoacacia is diploid and the only species to produce white flowers. In the native range, four natural hybrids have been described between black locust and the following 4 Robinia species:

1. Clammy locust, $R$. viscosa Vent. Their hybrid: $R . x$ ambigua Poir.,

2. New Mexico locust, $R$. neomexicana Gray. Their hybrid: R. $x$ holtii Beissn.

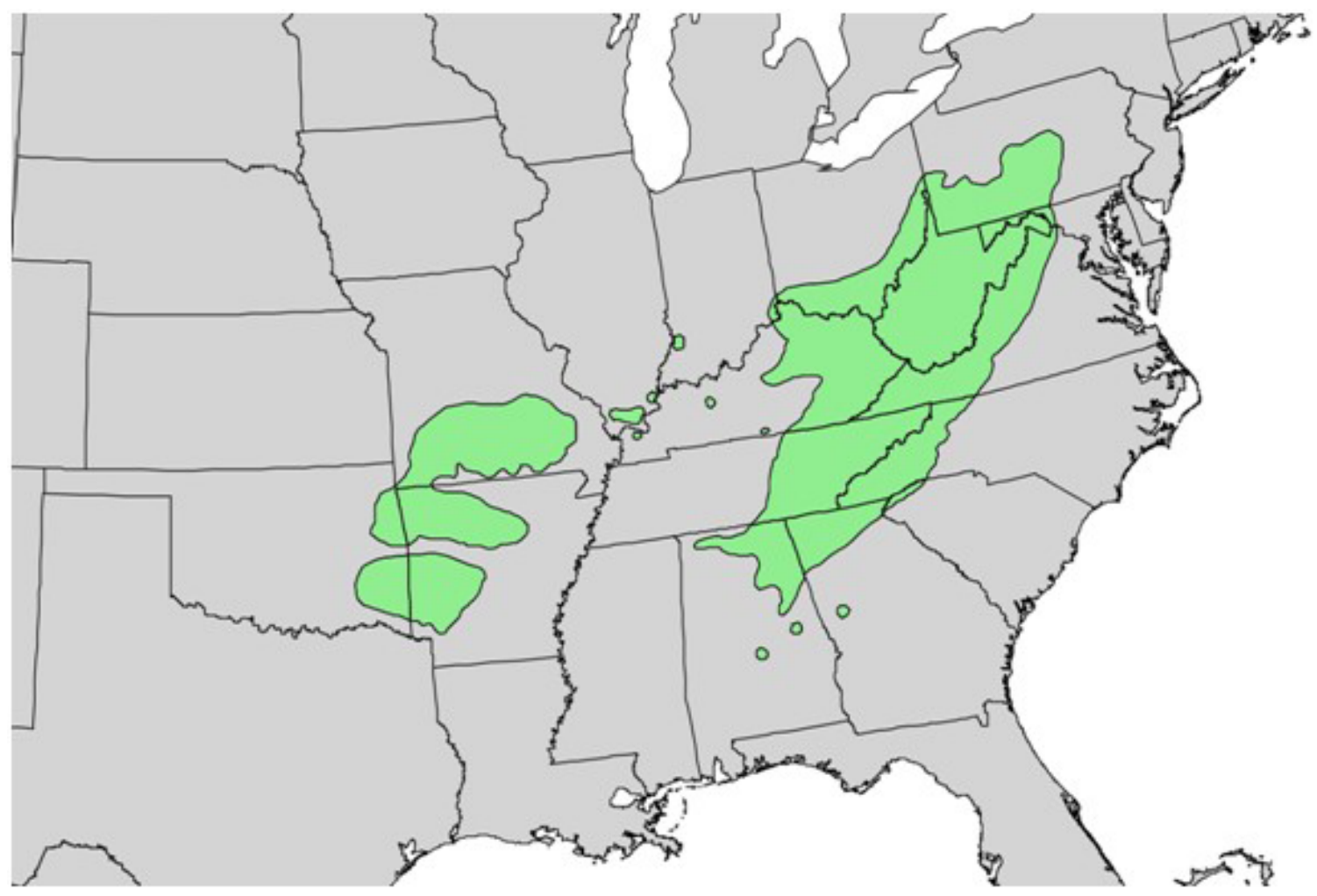

Figure 1. Distribution map of Robinia pseudoacacia (after Little 1971). 
3. Kelsey locust, R. kelseyi Hutch. Their hybrid: $R . x$ slavinii Rehd.,

4. Bristly locust, R. hispida L., their hybrid: R. x margarettia Ashe, (Little 1976).

\section{Genetic Variation}

\section{a. Adaptive genetic variation}

\section{Results of breeding efforts within the species natural range}

The potential of black locust as a fast-growing biomass plantation tree was revealed in a species trial where black locust was planted together with pine species and other hardwoods. This species trial was established in 1978 at various locations in Michigan. Although the survival of black locust was not striking, most probably due to harsh site conditions, it was the fastest growing species in the test (Miller et al. 1987). In another species trial, the growth of black locust was comparable to the growth of hybrid poplar (Miller et al. 1987).

A provenance test with one-year old seedlings, performed by the University of Georgia, revealed substantial within population variation for several traits, among others in time of leaf initiation, time of bud break, height, diameter, and number of pinnae. Nevertheless, no clear geographic trends were found (Kennedy 1983). Based on these results and on needs for high yielding biomass trees in Michigan, a long term breeding plan with black locust was initiated by Michigan State University (Mebrahtu and Hanover 1989). An open-pollinated progeny representing 434 families from the natural and naturalized range of black locust were tested at two sites in Michigan for height, thorn length, number of leaders, winter dieback, times of leaf initiation and drop (Mebrahtu and Hanover 1989). From the results of the combined analysis of data obtained one year after planting, significant family, and site differences existed for all traits. There were no apparent geographic patterns in variation for any of the studied traits. Family $x$ site interactions were non-significant except for winter dieback, which waives the need for separate breeding programs for specific sites.

In another provenance trial (Bongarten and Merkle 1996), seedlings from open pollinated families from 145 black locusts that were collected throughout the native range were measured for height and root collar diameter. Family growth measures were significantly correlated with latitude, longitude and elevation of origin. Height and diameter decreased, as origin was more northern, with latitude explaining $5-7 \%$ of the variation in family means.
Height and diameter were also generally greater in trees from western and low elevation populations. However, western and low elevation populations were mostly situated at southern latitudes. Once the effect of latitude was taken into account, multiple regressions showed no influence of longitude or elevation on seedling size.

In 1987, the so called "Steiner Group black locusts" were selected and released by the USDA Natural Resources Conservation Service. This group consists of three cultivars, 'Appalachia', 'Allegheny', and 'Algonquin', which represent native trees from the Appalachian Mountains. These cultivars were selected because of their excellent vigour, form (straight un-forked trunks), above average diameter, and above average borer resistance. (http:// www.nrcs.usda.gov/wps/portal/nrcs/site/national/home/).

The cultivation and breeding activities undertaken in the USA did not exclusively concentrate on yield improvement of black locust for energy purposes (Bongarten 1992, Bongarten et al. 1991, 1992, 1996, Mebrathu and Hanover 1989). Extensive black locust cultivation led to new varieties and cultivars. These include both ornamental varieties/cultivars/strains, suitable as street or garden trees and those more suitable for forestry. Further, in the USA research focuses also on resistance to borer insects, such as the locust stem borer (Megacyllene robinae Forster). This borer is a source of substantial damage, because its larvae make the wood unusable and weaken the trees leading to wind damage susceptibility. Heart rot (Fomes rimosus) can often follow borer attack, especially in older trees. Interestingly, these pests are generally absent from other countries where black locust has been naturalised or planted.

\section{Results of breeding efforts in Europe}

First selections for breeding programs were made from 'European' black locust stands established with material imported from the USA between 1710 and 1720 (Mebrathu and Hanover, 1989). Many varieties and cultivars of black locust have been bred during the several hundred years of cultivating this tree in Europe (see Straker et al. 2015 where characteristics of 20 bred varieties and cultivars are listed). In addition, herbicide (glufosinate ammonium) resistant transgenic black locust plants have been cultivated in Spain (Zaragoza et al. 2004). Using a colchicine treatment, tetraploid black locust plants have been produced (Ewald et al. 2009). Their tendency to display faster growth and higher stress tolerance than diploid clones has to be still verified by comparisons with the recent diploid clones. Nonetheless, these tetraploids could serve as a parent for breeding sterile triploid individuals.

Currently breeding and improvement on black locust is undertaken in Hungary, Bulgaria, France, Germany 
(Böhm et al. 2011), Greece (Dini-Papanastasi \& Panetsos 2000) and Poland (Kraszkiewicz 2013) using mainly European provenances.

Among the European countries, Hungary is the one with the most extensive breeding programs on black locust. Black locust plantations cover more than $20 \%$ of forest land; which is more than any other single tree species in Hungary (Rédei et al. 2010). In 1930, a black locust breeding program in Hungary was started focusing on fast growth, stem straightness, frost resistance, increased nectar yield, and prolonged flowering period (Keresztesi 1983). In the 1960s, Hungary had more black locust forests than the rest of European countries together (Rédei et al. 2008). At present, 35 different trials of this tree species are devoted to testing: growing technology (17 trials, see Rédei 1997, Rédei et al. 2006a, 2014), provenances and clones (10 trials, see Rédei et al. 2001, 2002b, 2002c, 2006b, 2013), spacing (2 trials, see Rédei \& Veperdi 2009), energy plantations (5 trials, see Rédei et al. 2002a, 2010, Rédei \& Veperdi 2009) and primary stoolbed (one trial).

In Bulgaria, 21 clonal tests were performed in order to select high productive and adaptive clones (Tsanov et al. 1992, Dimitrova 2005, Broshtilov 2009, Kalmukov 2009, and in http://www.fao.org/3/a-i3825e/i3825e07.pdf).

In Germany, 8 seed progenies representing provenances from East Germany, Hungary and India were planted on one site in 1999 in order to test the plant's viability, height, DBH and branching structure (Schneck et al. 2003). Results showed no significant difference in viability and biomass production among provenances after the first 13 years. The quality of the trees/trunks was unsatisfactory for all provenances, with only few individuals of ship mast stem-form.

Breeding and improvement research on black locust in Greece has concentrated on testing of effects of clonal selection on biomass production and biomass quality including crude protein content in leaves. In studies of Dini-Papanastasi $(2004,2008)$, selected clones of Robinia pseudoacacia var. monophylla Carr were compared with seedlings from open pollinated families, and seedlings of common black locust (Robinia pseudoacacia L.) aiming among others at selecting clones suitable for animal feeding. Dini-Papanastasi concluded that clonal selection can result in significant increase of biomass quantity and improvement of its quality. The clones had also significantly higher crude protein when compared to the families.

Breeding activities in France focus on identification of seed sources that could be valuable for reforestation in France. In the last 5 years, 11 trials have been planted using commercial seed lots from Russia and Romania, selected stand seed lots from France, Hungary and Romania as well as material from Hungarian seed orchards. Besides this, in 2015, a clonal test with French and Hungarian clones was started for identification of valuable genotypes (growth and shape), which can be used as base material for establishing a seed orchard (J.CH.Bastien personal communication). Further, France together with Portugal, Spain, the U.K. and Ireland contributes to the REINFORCE Arboretum \& Demonstration Sites Network (http://www.iefc. net/?langue $=$ en\&affiche page $=$ projet_REINFFORCE). In this network, 8 provenances (Hungary - 2, Bulgaria 2, Romania - 1, Slovakia - 1, FYROM - 1 and Turkey -1) are being tested in a vast range of environments. The main goal of the REINFORCE network is to identify species and provenances able to withstand and cope with the current weather conditions and future climates. Considering the young age of the network no results of provenance performances are available so far.

In summary, the main objectives of European black locust breeding were/are improving wood quality by breeding/ selecting straight trees for use as poles (Keresztesi 1983, Rédei 2002, 2013, Rédei et al. 2002c, d, 2006a, 2006b, 2007, 2008, 2013), increasing biomass production for energy purposes and cultivation in energy plantations (Keresztesi 1983, Ewald et al. 1992, Halupa et al. 1992, Naujoks et al. 1993, Dini-Papanastasi 2004, 2008, Liesebach et al. 2004, Rédei \&Veperdi 2009, Rédei et al. 2010, 2014, Dengiz et al. 2010, Böhm et al. 2011, Kraszkiewicz 2013), breeding for decorative purposes (Straker et al. 2015), frost tolerance (Keresztesi 1983, Rédei et al. 2001, 2002a, 2002b), for increasing flower nectar production and extension of the flowering period important for honey production (Rédei et. al 2002a, 2011), and breeding for animal feed associated with improving the caloric content (Dini-Papanastasi 2004). For future improvements, it is important to note that heritability and variation can vary depending on the trait in question and the age of the tree (Bloese et al. 1992). Caloric content (Stringer 1992), dry weight (Bloese et al. 1992), and net photosynthetic and respiration rates (Mebrahtu et al. 1993) seem to be highly heritable, whereas heritability of lignin content, specific gravity, and total extractives appear to be low (Stringer 1992). Variation in heritability was found for traits such as height, diameter, thorn length, dry weight, and photosynthetic rate (Mebrahtu and Hanover 1989, 1991).

\section{b. Neutral genetic variation}

There are five available studies on black locust, in which authors studied genetic diversity, genetic differentiation and structure of black locust in populations or progenies from the native range. Genetic markers used in these 
studies were either allozymes (Surles et al. 1989, Chang et al. 1998), isozymes (Liesebach et al. 2004), chloroplast DNA (Liesebach and Schneck 2012) or nuclear microsatellites (Houser 2014). The majority of the studied black locust populations, regardless of the marker used, were characterized by high genetic diversity. Majority of genetic diversity was found within populations, but genetic differentiation among them was low. Populations from the margin of the species' natural range had the highest differentiation rates (Surles 1989). Isolation by distance was the most probable explanation for genetic differentiation between populations. However, none of the studies identified clear genetic structure or geographic patterns of genetic diversity. Lack of patterns of geographic differentiation was attributed to widespread plantings of black locust from different, including European, seed sources (Surles 1989).

\section{Natural regeneration in Europe}

Black locust is a light demanding, insect pollinated, pioneer species occurring primarily in disturbed sites on fertile to poor, moist to dry soils (Cierjacks et al. 2013 and references therein). It reproduces sexually, and asexually by underground runners. Disturbance (e.g. mechanical stem or root damage, fire) favours clonal growth and leads to an increase in the number of ramets (suckers) and denser stands (Cierjacks et al. 2013, Kowarik 2010). Root sprouting is also common following silvicultural treatments. Nonetheless, sprouting can also emerge under the canopy and away from the parent tree without preceding disturbances (Kowarik 1996). Sprouting is considered as the primary mode of reproduction (Kowarik 1996, Liesebach and Schneck 2012 and references therein) and clonal structures of black locust covering areas of up to $100 \times 100 \mathrm{~m}$ were observed in the natural range (Chang et al. 1998). Sexual reproduction is an important strategy for reaching new habitats (Chang et al. 1998) as seed dispersal by wind and secondary dispersal on the ground, or by water, can facilitate long-distance dispersal (Kowarik 2010). Seeds are dispersed up to $67 \mathrm{~m}$ from the mother tree by wind (Morimoto et al. 2010) and over $1200 \mathrm{~m}$ by water (Säumel and Kowarik 2013), respectively. However, seed coat impermeability resulting in low germination rates of fresh seed ranging from $3.5 \%$ to $22 \%$, and high light requirements for germination limit reproduction by seed (Cierjacks et al. 2013 and references therein). Additionally, sexual regeneration of a genet might be reduced due to production of ramets (Jung et al. 2009).

Black locust starts fruiting at the age of six years, seed years occurring every one to two years (Huntley 1990). Seed production is best between 15 and 40 years of age and percentage of fruiting trees is similarly high in early successional and late-successional stands, while seed germination was lower in late successional stands in Berlin (Cierjacks et al. 2013). Genetic tests of black locust seeds showed that they are most likely pollinated by pollen donors from nearby; adjacent trees preferably recombine with each other (Surles et al. 1990). Self-pollination is assumed to be prevented by a hairy collar located directly below the stigma (Schütt 2010 cit. in Cierjacks et al. 2013). However, rare occurrence of albino seedlings might suggest absence of complete self-incompatibility or exposure to rare deleterious recessive alleles from other forms of consanguineous mating (Surles 1990). Despite both of them, clonal structuring and Wahlund effects, black locust is still highly outcrossing species (outcrossing rates ranging from 0.46 to 1.12) (Surles et al. 1990).

Because of dormancy, black locust seeds may persist in the soil for long periods of time accumulating in the seed bank (Stone 2009 and references therein), but longevity of seeds under natural conditions is not known (Cierjacks et al. 2013). Soil and forest stand disturbances result in germination of substantial amounts of seeds (Kowarik 2010, Radtke et al. 2013). Invasion (here as a spread and successful establishment beyond cultivation sites) of black locust is well documented during early succession on a whole range of different sites while the species becomes restricted to shrub and canopy layers in the absence of disturbance (Cierjacks et al. 2013 and references therein). Under closed canopy, in the shade, seeds are also able to germinate, but seedling mortality is high (Kowarik 1990). Although a significant role of both (sexual and asexual) reproduction modes for species persistence and expansion is generally acknowledged, studies, which would distinguish between them and/or characterize them when studying invasion, are largely missing.

Black locust is expected to spread vigorously in response to warming (Kleinbauer et al. 2010). Its ability not only to spread rapidly, but also to persist and adversely affect the ecosystems makes it an invasive species in parts of Europe, which is controlled in many areas of high nature conservation value (Cierjacks et al 2013 and references therein).

\section{References}

Böhm, C., Quinkenstein, A., Freese, D. (2011): Yield prediction of young black locust (Robinia pseudoacacia L.) plantations for woody biomass production using allometric relations. Annals of Forest Research 54(2): 215227.

Ewald, D, Naujoks G, Hertel H., and Eich J. (1992): Hat die Robinie in Brandenburg eine Zukunft? Allgem. Forstzeitschr. Stuttgart 14: 738-740. 
Ewald, D., Ulrich, K., Naujoks, G., and Schröder, M. B. (2009). Induction of tetraploid poplar and black locust plants using colchicine: chloroplast number as an early marker for selecting polyploids in vitro. Plant Cell Tissue Organ Cult 99: 353-357.

Bloese, P., Hanover, J., Bongarten, B. (1992): In: Hanover J, Miller K, Plesko S (eds) Proceedings: international conference on black locust: biology, culture, utilization. Department of Forestry, Michigan, State University, East Lansing, MI, pp 32-38.

Bongarten, B. (1992): In: Hanover J, Miller K, Plesko $S$ (eds). Proceedings: international conference on black locust: biology, culture, utilization. Department of Forestry, Michigan State University, East Lansing, MI, pp 78-97.

Bongarten, B. C., Merkle, S. A., Hanover, J. W. (1991): Genetically improved black locust for biomass production in short-rotation plantations. Energy from Biomass and Wastes XV (KLASS, DL ed.), Institute of Gas Technology, Chicago, IL, 391-409.

Bongarten, B. C., Huber, D. A., Apsley, D. K. (1992): Environmental and genetic influences on short-rotation biomass production of black locust (Robinia pseudoacacia L.) in the Georgia Piedmont. Forest Ecology and Management 55: 315-331.

Bongarten, B. C., Merkle, S.A. (1996): Optimizing energy yields in black locust through genetic selection: final report. United States. doi:10.2172/395580.

Broshtilov, K. (2009): Growth of white acacia (Robinia pseudoacacia L.) vegetative generations on habitat of average productivity where chromic luvisoils is available. Forestry Ideas 1: 166-176.

Chang, C. S., Bongarten, B., Hamrick, J. (1998): Genetic structure of natural populations of black locust (Robinia pseudoacacia L.) at Coweeta, North Carolina. Journal of Plant Research 111(1): 17-24.

Cierjacks, A., Kowarik, I., Joshi, J., Hempel, S., Ristow, M., von der Lippe, M., Weber, E. (2013): Biological Flora of the British Isles: Robinia pseudoacacia. Journal of Ecology 101:1623-1640

Dengiz, O., Gol, C., Sargioglu, F. E., and Edis, S. (2010): Parametric approach to land evaluation for forest plantation: A methodological study using GIS model. African Journal of Agricultural Research 5(12): 1482-1496.

Dini-Papanastasi, O., Panetsos, C. P. (2000): Relation between growth and morphological traits and genetic parameters of Robinia pseudoacacia var. monophylla DC in northern Greece. Silvae Genetica 49(1): 37-44.
Dini-Papanastasi, O. (2004): Contribution to the selection of productive progenies of Robinia pseudoacacia var. Monophylla Carr. from young plantations in Northern Greece. Forest Genetics 2: 113-123.

Dini-Papanastasi, O. (2008): Effects of clonal selection on biomass production and quality in Robinia pseudoacacia var. monophylla Carr. Forest Ecology and Management 256: 849-854.

Dimitrova, P. (2005): Eco-biological peculiarities of Robinia pseudoacacia L. on degraded terrains. Summary of PhD Thesis, Forest Research Institute, 1-36 (In Bulgarian, English summary).

Halupa, L., Keresztesi, B., and Rédei, K. (1992): The possibilities of acceleration of timber growing and utilization for energy and its development in Hungary. Rapport-Sveriges Lantbruksuniversitet.

Houser, C. (2014): Genetically-mediated leaf chemistry in invasive and native black locust (Robinia pseudoacacia L.) ecosystems. Thesis.

Huntley, J. C. (1990): Robinia pseudoacacia L. black locust. In: Burns, R. M., Honkala, B. H., (eds.) Silvics of North America. Volume 2. Hardwoods. Agriculture Handbook, No. 654. Washington DC, USA; USDA Forest Service: 755-761.

\section{http://plants.usda.gov/core/profile?symbol=ROPS}

http://www.iefc.net/?langue=en\&affiche_page=projet REINFFORCE.

http://www.nrcs.usda.gov/wps/portal/nrcs/site/national/ homel

Release Brochure for 'Appalachia', 'Allegheny', and 'Algonquin' Steiner Group black locust (Robinia pseudoacacia). USDA-Natural Resources Conservation Service, Norman A. Berg National Plant Materials Center, Beltsville, MD 20705. Published August 2007.

\section{http://www.fao.org/3/a-i3825e/i3825e07.pdf}

Jung, S. C., Matsushita, N., Wu, B. Y., Kondo, N., Shiraishi, A., Hogetsu, T. (2009): Reproduction of a Robinia pseudoacacia population in a coastal Pinus thunbergii windbreak along the Kujukurihama Coast, Japan. Journal of Forest Research 14: 101-110.

Kalmukov, K. (2009): Studies on Robinia pseudoacacia - a base for introduction of clones and cultivars of the species. Bulgarska Gora 2: 2 (In Bulgarian).

Kennedy, J. M. (1983): Geographic variation in black locust (Robinia pseudoacacia L.) M. Sc. Thesis. The University of Georgia. 
Keresztesi, B. (1983): Breeding and cultivation of black locust, Robinia pseudoacacia L., in Hungary. Forest Ecology and Management 6(3): 217-244.

Kleinbauer, I., Dullinger, S., Peterseil, J., Essl, F. (2010): Climate change might drive the invasive tree Robinia pseudoacacia L. into nature reserves and endangered habitats. Biol. Conserv. 143: 382-390.

Kraszkiewicz, A. (2013): Evaluation of the possibility of energy use black locust (Robinia pseudoacacia L.) dendromass acquired in forest stands growing on clay soils. Journal of Central European Agriculture 14(1): 388-399.

Kowarik, I. (1996): Funktionen klonalen Wachstums von Bäumen bei der Brachflächen-Sukzession unter besonderer Beachtung von Robinia pseudoacacia. Verhandlungen der Gesellschaft für Ökologie 26: 173-181.

Kowarik, I. (2010): Biologische Invasionen. Neophyten und Neozoen in Mitteleuropa, 2nd edn. Ulmer, Stuttgart, Germany.

Liesebach, H., Yang, M. S., Schneck, V. (2004): Genetic diversity and differentiation in a black locust (Robinia pseudoacacia L.) progeny test. Forest Genetics 2: 151-161.

Liesebach, H., Schneck, V. (2012): Chloroplast DNA variation in planted and natural regenerated stands of black locust (Robinia pseudoacacia L.). Silvae Genetica 61: $1-2$.

Little, E.L. (1976): Atlas of United States Trees. Vol. 3, Minor Western Hardwoods. U.S. Department of Agriculture Miscellaneous Publication 1314. U.S. Department of Agriculture, Washington D.C.

Mebrahtu, T., Hanover, J. W. (1989): Heritability and expected gain estimates for traits of black locust in Michigan. Silvae Genetica 38 (3-4): 125-130.

Mebrahtu, T., Hanover, J.W. (1991): Family variation in gas exchange, growth and leaf traits of black locust half-sib families. Tree Physiology 8:185-193.

Mebrahtu, T., Layne, D., Hanover, J., Flore, J. (1993): Net photosynthesis of black locust seedlings in response to irradiance, temperature, and $\mathrm{CO}_{2}$. Photosynthetica 28: 45-54.

Miller, R. O., Bloese, P. D., Hanover, J. W. (1987): Black locust: A superior short-rotation intensive culture species for biomass production in the lake states. Proc. Eleventh Ann. Mtg. On Energy from Biomass and Wastes, Institute of Gas Technology, Orlando, Fl.
Naujoks, G.,Hertel,H., Ewald,D. (1993): Geradschaftige Robinien-eine Baumart fuer Ausgliederungsflaechen. Mitteilungen der Bundesforschungsanstalt fuer Forst-und Holzwirtschaft (Germany). no. 172.

Radtke, A., Ambraß, S., Zerbe, S., Tonon, G., Fontana, V., Ammer, C. (2013): Traditional coppice forest management drives the invasion of Ailanthus altissima and Robinia pseudoacacia into deciduous forests. Forest Ecology and Management 291: 308-317.

Rédei, K. (1997): The Effect of Regeneration Methods on the Yield of Black Locust (Robinia pseudoacacia L.) Stands in Hungary. Silva Lusitana 5(1): 71-77.

Rédei, K., Osváth-Bujtás, Z., Balla, I. (2001): Propagation methods for black locust (Robinia pseudoacacia L.) improvement in Hungary. Journal of Forestry Research 12(4): 215-219.

Rédei, K. (2002): Management of black locust (Robinia pseudoacacia L.) stands in Hungary. Journal of Forestry Research 13(4): 260-264.

Rédei, K., Osváth-Bujtás, Z., Balla, I. (2002a): Clonal approaches to growing black locust (Robinia pseudoacacia) in Hungary: a review. Forestry 75(5): 547-552.

Rédei, K., Osvath-Bujtas, Z., Lee, K. J. (2002b): Selection and management of black locust (Robinia pseudoacacia L.) in Hungary for timber and honey production and landscape. Journal of Korean Forestry Society 91(2): 156162.

Rédei, K., Osvath-Bujtas, Z., Naydenova, T., Raev, I., Alexandrov, A., Rossnev, B., Grozeva, M. (2002c): Yield and management of black locust (Robinia pseudoacacia L.) cultivars in Hungary. In Study, conservation and utilisation of forest resources. Proceedings of the Third Balkan Scientific Conference, Sofia, Bulgaria, 2-6 October 2001. Volume I. (pp. 293-300). Forest Research.

Rédei, K., Naydenova, T., Raev, I., Alexandrov, A., Rossnev, B., Marinov, I., Grigorov, G. (2002d): The main characteristics of black locust (Robinia pseudoacacia L.) management in Hungary. In Study, conservation and utilisation of forest resources. Proceedings of the Third Balkan Scientific Conference, Sofia, Bulgaria, 2-6 October 2001. Volume I. (pp. 285-292). Forest Research Institute.

Rédei, K., Veperdi, I., Meilby, H. (2006a): Stand structure and growth ofmixed white poplar (Populus alba L.) and black locust (Robinia pseudoacacia L.) plantations in Hungary. Acta Silvatica et Lignaria Hungarica 2: 23.

Rédei, K., Osváth-Bujtás, Z., Veperdi, I. (2006b): Black locust (Robinia pseudoacacia L.) clonal seed orchards in Hungary. Silva Balcanica 7: 63-68. 
Rédei, K., Osváth-Bujtás, Z., Keserü, Z., Park, Y. G. (2007): Clonal selection of black locust (Robinia pseudoacacia L.) in Hungary: a review. Journal of Apiculture 22: 189-193.

Rédei, K., Osváth-Bujtás, Z., Veperdi, I. (2008): Black locust (Robinia pseudoacacia L.) improvement in Hungary: a review. Acta Silvatica et Lignaria Hungarica 4: 127-132.

Rédei, K., Veperdi, I. (2009): The role of black locust (Robinia pseudoacacia L.) in establishment of shortrotation energy plantations in Hungary. International Journal of Horticultural Science 15: 41-44.

Rédei, K., Veperdi, I., Tomé, M., Soares, P. (2010): Black Locust (Robinia pseudoacacia L.) Short - Rotation Energy Crops in Hungary: a Review. Silva Lusitana 18(2): 217- 223.

Rédei, K., Csiha, I., Keserü, Z. (2011): Characteristics of Robinia ambigua Poir decaisneana cv. 'Rózsaszín - AC' - as bee forage. Hungarian Agricultural Research 20.1: 21- 23.

Rédei, K., Keserü, Z., Rásó, J. (2013): Early evaluation of micropropagated black locust (Robinia pseudoacacia L.) clones in Hungary. Forest Science and Practice 15(1): 8184.

Rédei, K. (2013): Black Locust (Robinia pseudoacacia L.) Growing in Hungary. Publications of the Hungarian Forest Research Institute.

Rédei, K., Csiha, I., Keserü, Z., Rásó, J., J., Kamandiné Végh, A. Antal, B. (2014): Growth and Yield of Black Locust (Robinia pseudoacacia L.) Stands in Nyírség Growing Region (North-East Hungary). South-east Eur for 5 (1): 13-22.

Schiffman, P. M., Johnson, W. C. (1992): Sparse buried seed bank in a southern Appalachian oak forest: implications for succession. American Midland Naturalist 127: 258-267.

Schneck, V., Hertel, H., Yang, M. S. (2003): Prüfung von Nachkommenschaften ausgewählter Robinienbestände - Konzept, Anzuchtphaseund Populationsstruktur. In: Neue Baumarten im deutschen und europäischen Recht für forstliches Vermehrungs Bayerisches Amt für forstliche Saat-und Pflanzenzucht (Herausg.). Tagungsbericht der 25. Internat. Tagung $d$. Arbeitsgemeinschaft $f$. Forstgenetik u. Forstpflanzenzüchtung, Teisendorf, 2325. Oktober 2002, 111-118.
Stone, K. R. (2009): Robinia pseudoacacia In: Fire Effects Information System, [Online]. (F. S. Laboratory, Hrsg.), retrieved on 10.11.2015 from U.S. Department of Agriculture, Forest Service, Rocky Mountain Research Station: http://www.fs.fed.us/database/feis/plants/tree/ robpse/all.html

Straker, K. C., Quinn, L. D., Voigt, T. B., Lee, D. K., Kling, G. J. (2015): Black Locust as a Bioenergy Feedstock: a Review. Bioenerg. Research 2015: 1-19.

Stringer, J. (1992): Wood properties of black locust (Robinia pseudoacacia). In: Hanover J, Miller K, Plesko $S$ (eds) Proceedings: international conference on black locust: biology, culture, utilization. Department of Forestry, Michigan State University, East Lansing, MI, pp 197-207.

Säumel, I., Kowarik, I. (2013): Propagule morphology and river characteristics shape secondary water dispersal in tree species. Plant Ecology 214: 1257-1272.

Surles, S. E., Hamrick, J. L., Bongarten, B. C. (1989): Allozyme variation in black locust (Robinia pseudoacacia). Canadian Journal of Forest Research 19: 471-479.

Surles, S. E., Hamrick, J. L., Bongarten, B. C. (1990): Mating systems in open-pollinated families of black locust (Robinia pseudoacacia). Silvae Genetica 39(1): 35-40.

Tsanov, Ts., Ya. Naydenov, K. Kalmukov, Broshtilov, K. (1992): Initial results from testing certain clones of false acacia (Robinia pseudoacacia L.). Forest Science - Sofia, 4, 24-31 (In Bulgarian, English summary).

Zaragoza, C., Munoz-Bertomeu, J., Arrillaga, I. (2004): Regeneration of herbicide-tolerant black locust transgenic plants by SAAT. Plant Cell Reports 22(11): 832-838. 

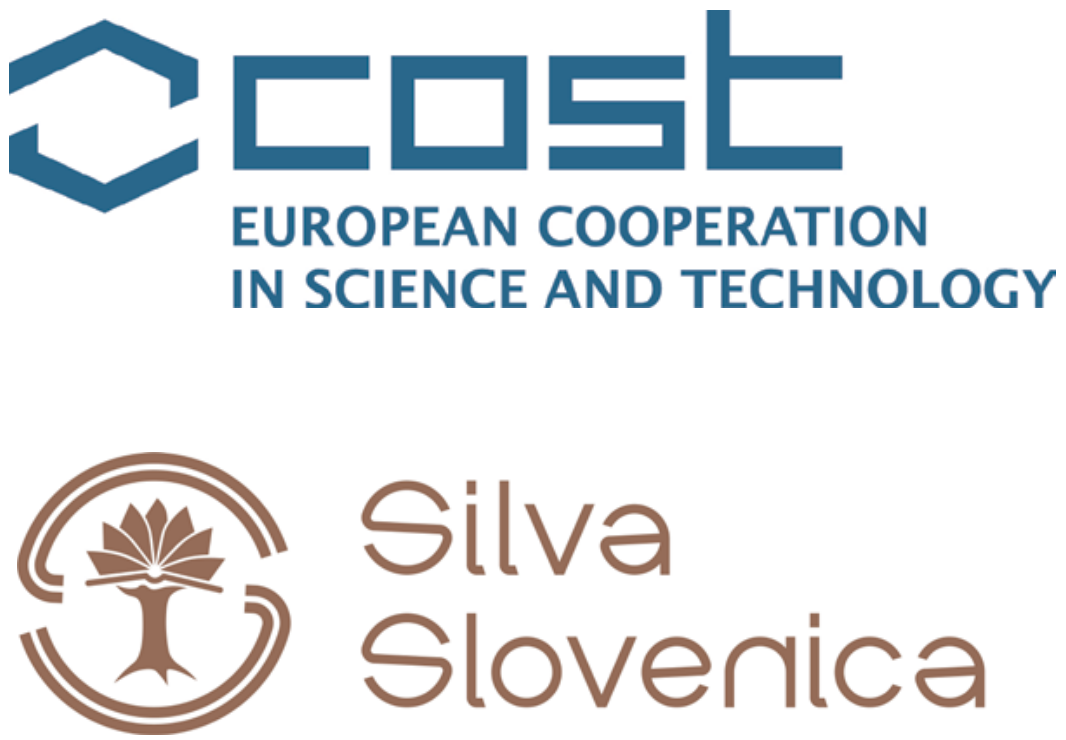